The Inskip Formation, the Harmony Formation, and the Havallah Sequence of Northwestern Nevada-An Interrelated Paleozoic Assemblage in the Home of the Sonoma Orogeny

Professional Paper 1757 

The Inskip Formation, the Harmony Formation, and the Havallah Sequence of Northwestern Nevada_An Interrelated Paleozoic Assemblage in the Home of the Sonoma Orogeny

By Keith B. Ketner

Professional Paper 1757 


\section{U.S. Department of the Interior DIRK KEMPTHORNE, Secretary}

\section{U.S. Geological Survey \\ Mark D. Myers, Director}

\section{U.S. Geological Survey, Reston, Virginia: 2008}

For product and ordering information:

World Wide Web: http://www.usgs.gov/pubprod

Telephone: 1-888-ASK-USGS

For more information on the USGS - the Federal source for science about the Earth, its natural and living resources, natural hazards, and the environment:

World Wide Web: http://www.usgs.gov

Telephone: 1-888-ASK-USGS

Any use of trade, product, or firm names is for descriptive purposes only and does not imply endorsement by the U.S. Government.

Although this report is in the public domain, permission must be secured from the individual copyright owners to reproduce any copyrighted materials contained within this report.

Suggested citation:

Ketner, Keith B., 2008, The Inskip Formation, the Harmony Formation, and the Havallah Sequence of Northwestern Nevada_-An Interrelated Paleozoic Assemblage in the Home of the Sonoma Orogeny: U.S. Geological Survey Professional Paper 1757, 21 p. 


\section{Contents}

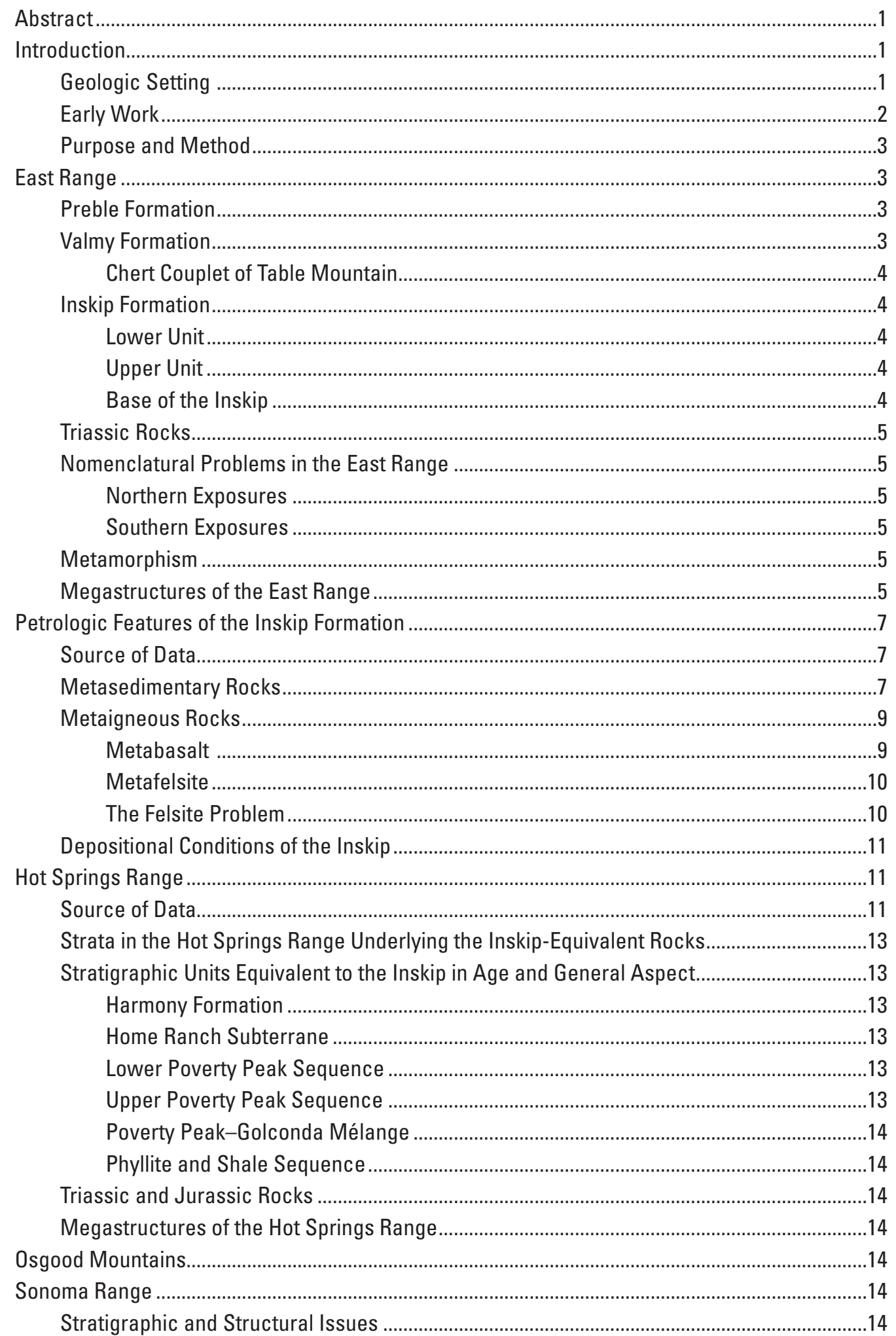




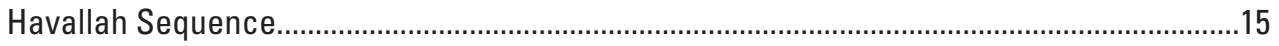

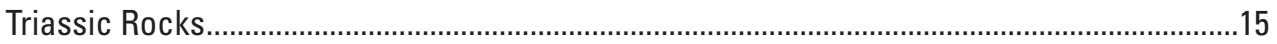

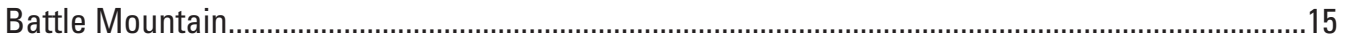

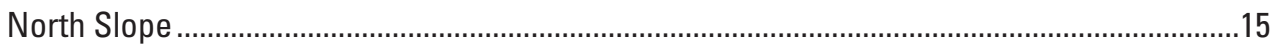

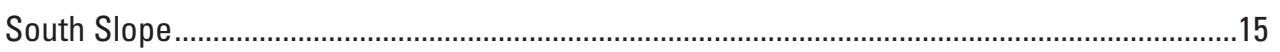

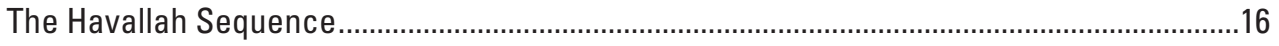

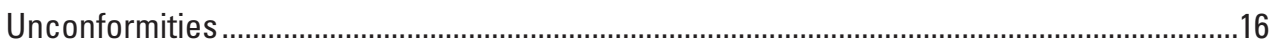

Relation of the Inskip and the Harmony Formations to the Havallah Sequence in the Arkosic

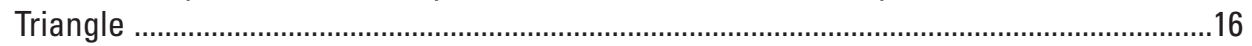

Sonoma Orogeny and Golconda Thrust..................................................................................

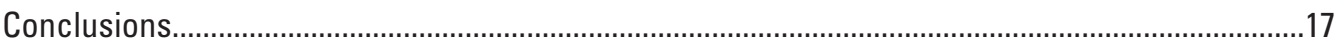

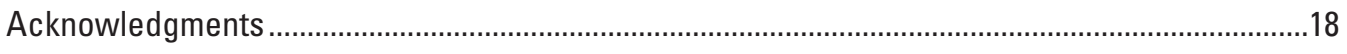

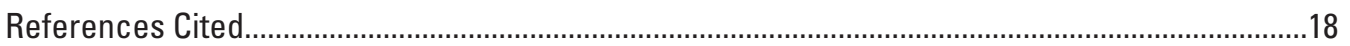

\section{Figures}

1. Map showing northwestern Nevada the locations of figures 2 and 11. Also shown, in the inset outline of Nevada, are the locations of the arkosic triangle and the area shown in figure 1 .

2. Map showing the central part of the East Range modified from Whitebread (1994), Whitebread and Sorensen (1983), and Johnson (1977) .........................................6

3-10. Photographs showing:

3. Sheared arkosic sandstone from the lower Inskip Formation. Clasts are quartz, quartzite, K-feldspar, and plagioclase

4. Unpolarized view of figure 3 .

5. Coarse arkosic sandstone from a massive bed in the lower Inskip Formation. This specimen shows no evidence of shear. Crossed polarizers

6. Chert from the uppermost part of the Inskip Formation. The carbon-rich stylolites are preserved in this specimen, and radiolarians are sporadically preserved in others. The only effect of the relatively slight metamorphism was to slightly increase the grain size. Unpolarized

7. Metabasalt from the upper member of the Inskip Formation. Megacrysts are magnesian hornblende, groundmass is albite and ilmenite. This specimen shows slight evidence of shear. Crossed polarizers.

8. Relatively unsheared porphyritic felsite from the upper part of the Inskip Formation. Megacrysts are albite, groundmass is quartz and biotite. Crossed polarizers

9. Sheared felsite from the lower part of the Inskip Formation. Light bands are albite and quartz, medium bands are muscovite, dark bands are biotite. Uncrossed polarizers

10. Sheared porphyritic felsite from the Rochester Rhyolite at the base of the Triassic sequence immediately overlying the Inskip Formation. Megacrysts are albite, groundmass is albite, quartz, and muscovite. 
11. Generalized and simplified map showing part of the Hot Springs Range modified from Jones (1997a, b) showing the Hot Springs Range syncline and the northern Hot Springs Range anticline.....

\section{Tables}

1. Chemical composition of metabasalt of the Inskip Formation, East Range, Nevada......10

2. Chemical composition of metafelsites of the Inskip Formation and the Triassic Rochester Rhyolite, East Range 



\title{
The Inskip Formation, the Harmony Formation, and the Havallah Sequence of Northwestern Nevada-An Interrelated Paleozoic Assemblage in the Home of the Sonoma Orogeny
}

\author{
By Keith B. Ketner
}

\section{Abstract}

An area between the towns of Winnemucca and Battle Mountain in northwestern Nevada, termed the arkosic triangle, includes the type areas of the middle to upper Paleozoic Inskip Formation and Havallah sequence, the Upper Devonian to Mississippian Harmony Formation, the Sonoma orogeny, and the Golconda thrust. According to an extensive body of scientific literature, the Havallah sequence, a diverse assemblage of oceanic rocks, was obducted onto the continent during the latest Permian or earliest Triassic Sonoma orogeny by way of the Golconda thrust. This has been the most commonly accepted theory for half a century, often cited but rarely challenged. The tectonic roles of the Inskip and Harmony Formations have remained uncertain, and they have never been fully integrated into the accepted theory. New, and newly interpreted, data are incompatible with the accepted theory and force comprehensive stratigraphic and tectonic concepts that include the Inskip and Harmony Formations as follows: middle to upper Paleozoic strata, including the Inskip, Harmony, and Havallah, form an interrelated assemblage that was deposited in a single basin on an autochthonous sequence of Cambrian, Ordovician, and lowest Silurian strata of the outer miogeocline. Sediments composing the Upper Devonian to Permian sequence entered the basin from both sides, arkosic sands, gravel, limestone olistoliths, and other detrital components entered from the west, and quartz, quartzite, chert, and other clasts from the east. Tectonic activity was expressed as: (1) Devonian uplift and erosion of part of the outer miogeocline; (2) Late Devonian depression of the same area, forming a trough, probably fault-bounded, in which the Inskip, Harmony, and Havallah were deposited; (3) production of intraformational and extrabasinal conglomerates derived from the basinal rocks; and (4) folding or tilting of the east side of the depositional basin in the Pennsylvanian. These middle to upper Paleozoic deposits were compressed in the Jurassic, causing east-verging thrusts in the eastern part of the depositional basin (Golconda thrust) and west-verging thrusts and folds in the western part. Hypotheses involving a far-traveled allochthon that was obducted from an ocean or back-arc basin are incompatible with modern observations and concepts.

\section{Introduction}

\section{Geologic Setting}

This report concerns middle to upper Paleozoic rocks in an area of northwestern Nevada, between the towns of Winnemucca and Battle Mountain, termed the "arkosic triangle" (Ketner and others, 2005). This area (fig. 1) includes the type section of the Inskip Formation, the Harmony Formation, the Havallah sequence, the type Sonoma orogeny, and the type area of the Golconda thrust. For many years, tectonic theories regarding middle to upper Paleozoic rocks of this area have held that the Havallah sequence, a mostly deepwater deposit, comprises a far-traveled allochthon that was displaced from basins to the west by way of the Golconda thrust in the Late Permian or Early Triassic. A link between the Golconda thrust and the Sonoma orogeny was commonly assumed. The enigmatic Inskip and Harmony Formations were not fully integrated into stratigraphic and tectonic concepts.

The present report uses new and old evidence to integrate the three named stratigraphic units, to downgrade the regional importance of the Sonoma orogeny, to reduce the extent of the Golconda thrust, and to revise the age of that thrust.

The Inskip Formation, the Harmony Formation, and the Havallah sequence constitute a structurally disrupted stratigraphic assemblage that records a history of extreme tectonic and igneous activity from the Devonian to the Permian. Only recently have their ages become reasonably accurate as cited in the present work. Therefore, only recently has it become possible to construct a tectonic theory that involves all the middle to upper Paleozoic sequences and is applicable both to the arkosic triangle and regionally.

An understanding of the stratigraphy and structure of the East Range, including the Inskip Formation, is essential 


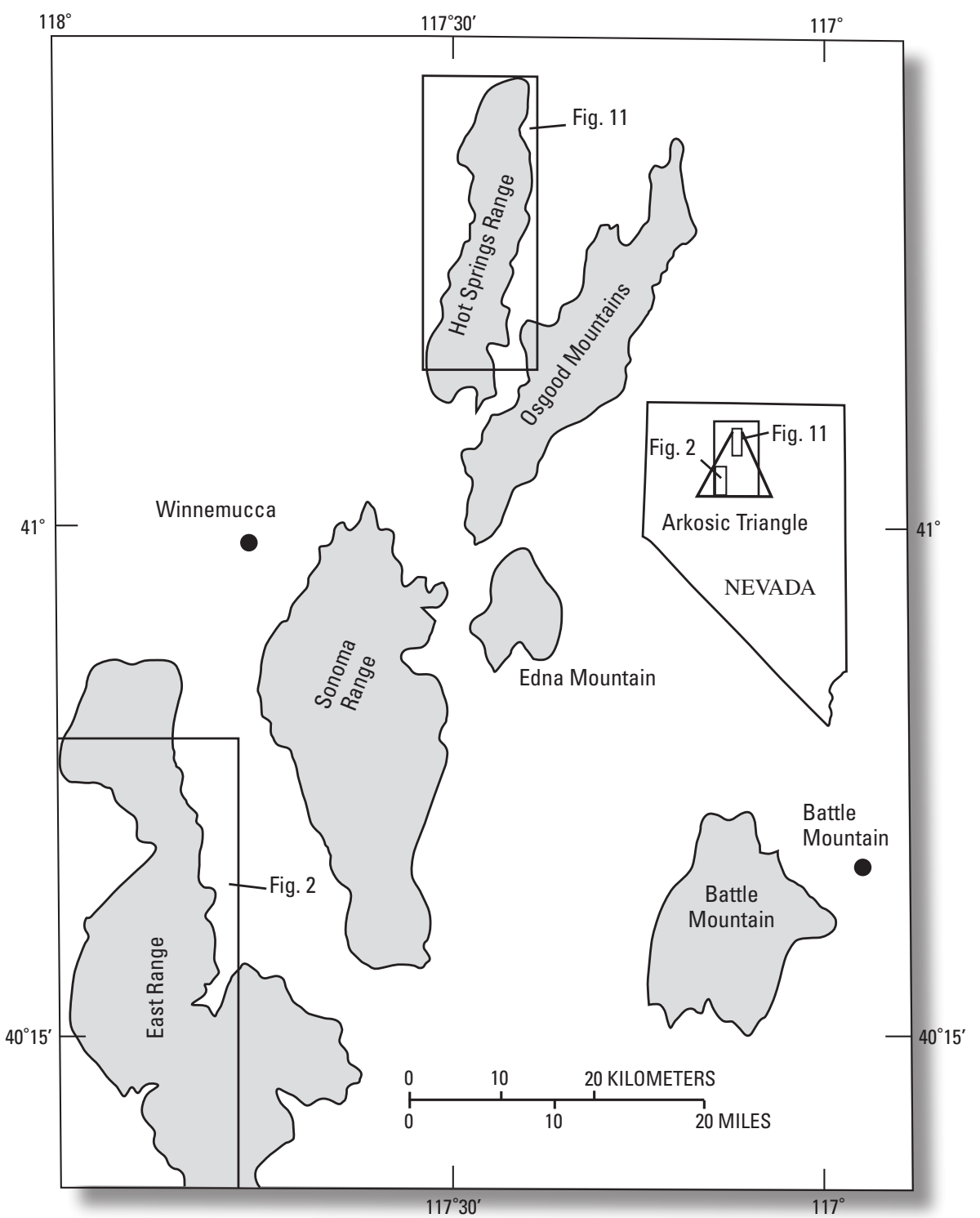

Figure 1. Northwestern Nevada showing the locations of figures 2 and 11. Also shown, in the inset outline of Nevada, are the locations of the arkosic triangle and the area shown in figure 1. for an understanding of the stratigraphy and tectonics of the region; consequently, the rocks of this range, especially the Inskip Formation, are herein described in detail. Other areas in the arkosic triangle have been well described in numerous publications, some of which are cited. The Upper Devonian to Mississippian parts of the Inskip Formation and of the correlative sequences described here have a very conspicuous feature in common-coarse-grained arkosic sedimentary strata. These coarse-grained arkosic rocks are unique in Nevada and call for a unique explanation of origin. The ages of detrital zircons in these rocks point to an origin in northwestern Canada (Gehrels and Dickinson, 2000; Gehrels and others, 2000). That fact plus the coarse grain size and immaturity of the arkosic deposits led to the theory that the arkosic sediments were eroded from a part of the North American plate that rifted away from the continent at the latitude of northern British Columbia and drifted southward to the latitude of Nevada. From this position it shed coarse arkosic sediments eastward to the arkosic triangle in Late Devonian to Mississippian time (Ketner and others, 2005). Supporting this theory is the presence, at the base of the arkosic deposits, of large olistoliths that contain Cambrian Archaeocyathids endemic to northwestern Canada and other distant northern locations (DeBrenne and others, 1990). The dimensions of some of these olistoliths, measured in meters, imply a very close source area.

\section{Early Work}

The standard regional model of Paleozoic tectonism, including the Sonoma orogeny and Golconda thrust, evolved in northwestern Nevada and was published in the form of reconnaissance maps and commentary by Ferguson and others (1951, 1952) and Muller and others (1951). Their pioneering 
efforts, made difficult by a scarcity of reliable paleontological dating, were supplemented later by frequently quoted papers by Roberts and others (1958) and Silberling and Roberts (1962). Subsequent pertinent maps and accounts are cited in the following sections.

\section{Purpose and Method}

The purpose of this report is to describe the lithic composition of the Inskip Formation of the East Range, establish its relation to correlative strata of the Hot Springs Range, and integrate those two sequences into the regional stratigraphy and structure. In addition, an attempt is made to reduce the Sonoma "orogeny" to a minor, local event and to revise the age of the Golconda thrust. More than 150 samples of the Inskip were collected and sectioned for petrologic examination, and $\mathrm{X}$-ray diffraction diagrams were made of almost all of them. Eleven samples of igneous rocks were analyzed chemically. In the following paragraphs, the stratigraphy and structure of the East Range are discussed, followed by a detailed description of the Upper Devonian to Permian Inskip Formation.

\section{East Range}

\section{Preble Formation}

The oldest rocks exposed in the East Range are predominantly carbonate strata, here correlated with the type Preble Formation of Cambrian and Early Ordovician age (fig. 2). Lower beds have been altered so intensely by a combination of regional and contact metamorphism that the original composition and bedding features are obscure. Upper beds are graded and consist of interbedded limestone, quartzose detrital sediments, and tabular bodies of metabasalt near the boundary with the overlying Valmy Formation.

The uppermost beds of the Preble, just below the Valmy Formation, contain conodonts that, in two places, have been dated at the boundary between latest Cambrian and earliest Ordovician age (Whitebread, 1994) and a collection from SE 1/4, sec. 12, T. 30 N., R. 36 E., Bartomes Spring quadrangle, identified by John Repetski (written commun., 2000). Lower beds are paleontologically undated but are interpreted, from their stratigraphic position and general resemblance to the type Preble Formation (Hotz and Willden, 1964), to be of Middle to Late Cambrian age. The Preble Formation is regarded as autochthonous, as it overlies the Osgood Mountain Quartzite with a sedimentary contact in the Osgood Mountains (Hotz and Willden, 1964). This quartzite unit is generally correlated with the Prospect Mountain Quartzite, a well-established formation of the miogeocline.

On some published maps of the East Range, the Preble is designated as being of Triassic age (Ferguson and others, 1951; Muller and others, 1951; Johnson, 1977; Stewart and Carlson, 1978). This resulted in long-lasting misinterpretations of the tectonic history of the region because it seemed to mandate a major thrust fault separating the Preble from the overlying Valmy Formation. A fault is no longer necessary; the two formations are in sequential stratigraphic order and, in fact, the contact is depositional and gradational as described in the next section.

\section{Valmy Formation}

The term Valmy Formation has been applied by many authors to relatively deepwater, siliceous deposits of known Ordovician age in northern Nevada. In the East Range, lower strata of the Valmy consist mainly of argillite, chert, greenstone, and limestone. Middle strata are mainly quartzite and minor interbedded chert, argillite, and greenstone. Upper strata are mainly shale, siltstone, greenstone, and chert.

In the East Range, conodonts from the older beds are of Early to Middle Ordovician age (Whitebread, 1994; Ketner and others, 2000). Massive quartzite beds in the middle of the formation are regarded as Middle Ordovician on the basis of their stratigraphic position and lithic correlation with dated strata elsewhere. The boundaries of Lower, Middle, and Upper Ordovician in terms of their paleontological content, as used here and in earlier publications on the Inskip Formation by Ketner and others $(2000,2005)$, are longstanding and are comparable with usage in older publications. Readers should note, however, that boundaries between these intervals worldwide have been changed in terms of their paleontological content as described by Webby and others (2004). The principal result, locally, is to move the massive quartzite unit of the Valmy from the Middle to the Upper Ordovician.

The Valmy Formation has been wholly or partly displaced by low-angle faults in many parts of Nevada, but in the East Range the Valmy is autochthonous as it overlies the Preble Formation with a depositional, gradational contact. This contact is clearly exposed $2 \mathrm{~km}$ east of Kyle Hot Springs in the Bartomes Spring 7.5-minute quadrangle and somewhat less clearly near the center of sec. 6, T. 31 N., R. 37 E., in the Dun Glen quadrangle (Whitebread, 1994). The East Range is not unique in this respect, as indicated by the following examples. In northern Nevada, gradational, depositional contacts between autochthonous Cambrian carbonate strata and the Valmy Formation are well exposed in the Bull Run Mountains (Ketner and others, 1993) and at Bearpaw Mountain (Ketner and others, 1995) where the contact zone is dated at the Cambrian-Ordovician boundary by conodont collections. In southern Nevada the gradational contact between a Cambrian carbonate unit and the Valmy-equivalent Palmetto Formation is exposed in the Montezuma Range at Railroad Pass where the gradational nature of the contact is confirmed by numerous conodont collections (Repetski and Ketner, unpub. data, 1993). The precise locations of these and other exposures are recorded in a previous publication (Ketner, 1998). 
Inskip Formation, Harmony Formation, and Havallah Sequence of Northwestern Nevada

\section{Chert Couplet of Table Mountain}

A conspicuous bedded chert couplet exposed on the east side of Table Mountain in the central part of the East Range (Ketner and others, 2000) is composed of a lower member of black chert and an upper member of thickly bedded white chert. The combined members, commonly less than $10 \mathrm{~m}$ thick, lie at the top of the Valmy Formation regionally. The age of the couplet, where it is well represented in northeastern Nevada, is latest Ordovician and Early Silurian (Ketner, 1991; Ketner and Ross, 1990; Noble and others, 1997). In many exposures regionally, the upper member of this couplet is mineralized and discolored by oxidation of sulfides. On many published maps, the chert couplet has been included in the Valmy Formation, and that practice is continued here.

\section{Inskip Formation}

The name Inskip Formation is used exclusively in the East Range and, on most published maps, is applied only to a thick marine sequence of strata exposed on the west side of the range where it overlies the Ordovician Valmy Formation disconformably (Whitebread, 1994). The significance of the Inskip Formation was not understood at first, owing to scarcity of paleontologic dating and lack of accurate petrologic data. The formation therefore did not figure significantly into the early formulation of stratigraphic, structural, and tectonic concepts.

The thickness of the Inskip is somewhat uncertain owing to incomplete exposure, internal folding, possible inconspicuous faults, and bedding-parallel shearing strain. In this report, the Inskip is divided into the same lower and upper stratigraphic units designated by Whitebread (1994).

\section{Lower Unit}

The lower unit of the Inskip consists of arkosic conglomerate and arkosic sandstone, shale, limestone, basalt, and felsite. Basalt and felsite are scarce relative to their presence in the upper unit. Composition of clasts in the conglomerate and sandstone, roughly in order of abundance, are quartz, quartzite, feldspar, arkosic sandstone, siltstone, shale, and radiolarian chert. Sparse limestone sequences, commonly a few meters thick, are recrystallized, and all contain abundant siliceous detrital grains. A rough estimate of the thickness of the lower unit based on Whitebread (1994) is about $1 \mathrm{~km}$.

Corals and conodonts from limestone beds, the only fossils that have been reported, are extremely rare. One limestone sample collected from the lowest beds of the Inskip contains conodonts of Late Devonian to Mississippian age (locations shown in Whitebread, 1994, and Ketner and others, 2000). Those fossils recovered from the lower but not lowest part of the Inskip, formerly thought to be long-ranging (Whitebread, 1978), have been reevaluated and are now regarded as indicating an Osagean, late Early Mississippian age (Ketner and others, 2000). Corals collected from the lower part are of Meramecian age, early Late Mississippian (Sando, 1993). No direct evidence exists of beds of Pennsylvanian age in the Inskip, possibly due to the general scarcity of fossils or a depositional hiatus.

\section{Upper Unit}

The upper unit of the Inskip consists of abundant tabular and irregular bodies of basaltic and felsitic rocks interstratified with quartzite, shale, and sparse arkosic and limy beds. High in the upper unit are fine-grained, highly quartzose strata containing abundant stylolites. These strata, which are minimally sheared, are interpreted to be somewhat recrystallized bedded chert. The thickness of the upper unit, in spite of the uncertainties listed above, is at least $1 \mathrm{~km}$. One limestone outcrop, high in the sequence, among strata interpreted to be altered chert, yielded Permian and reworked Early Pennsylvanian conodonts (Ketner and others, 2000).

\section{Base of the Inskip}

As originally mapped and described by Ferguson and others (1951), the Inskip lies with a concordant sedimentary contact on the Ordovician Valmy Formation (then called Leach Formation). Later, this contact was stated by Silberling and Roberts (1962, p. 13) to be "for the most part steeply faulted" and was shown on their sketch map as entirely faulted. Whitebread (1994) mapped it in detail as a sedimentary contact. I concur with Whitebread and with Ferguson and others because the contact of the Inskip with the Valmy Formation is remarkably parallel with bedding, above and below, along its entire exposed length of $20 \mathrm{~km}$, and the stratigraphic base of the Inskip is in contact with the stratigraphic top of the Cambrian-Ordovician sequence, a perfectly normal disconformable depositional succession. Moreover, pebbles and cobbles of quartzite in the Inskip are lithically identical to quartzite beds in the underlying Valmy. The concept of Hargett and others (2000) that the Valmy has been thrust over the Inskip is structurally impossible, given that the stratigraphic base of the Inskip is in concordant contact with the stratigraphic top of the Valmy. The disconformity between these two units, and the coarsegrained arkosic beds of the Inskip, are local expressions of the Late Devonian to Early Mississippian Antler orogeny. The disconformable nature of the contact indicates uplift and erosion, but structural evidence of folding and thrust faulting during that event are entirely lacking here. Because such a relationship is contrary to generally accepted beliefs, additional support is offered. The East Range is not unique in this respect. Several other exposures in Nevada display concordant depositional contacts between lower Paleozoic deepwater sequences and overlying Late Devonian to Mississippian strata. The precise locations of some of these 
exposures are recorded in a previous publication (Ketner, 1998).

\section{Triassic Rocks}

In the East Range, a thick sequence of Triassic strata lies concordantly on Paleozoic strata. Most of these are sedimentary rocks, but the basal unit is the Rochester Rhyolite, a member of the Koipato Group. It lies concordantly on the uppermost exposures of the Inskip Formation.

\section{Nomenclatural Problems in the East Range}

\section{Northern Exposures}

The terms Inskip and Havallah have been applied inconsistently to upper Paleozoic deepwater strata in the East Range. Immediately north of Rockhill Canyon in the Dun Glen quadrangle (Whitebread, 1994), a small area of limestone, chert, basalt, felsite, and arkosic rock was originally mapped as Inskip by Ferguson and others (1951) and as Havallah Formation by subsequent authors (Silberling and Roberts, 1962; Johnson, 1977; Stewart and Carlson, 1978; Whitebread, 1994). Most of these rocks appear to be somewhat less metamorphosed than strata assigned by all of those authors to the Inskip Formation, and these rocks are separated from the uncontested Inskip by a reverse or thrust fault, the Willow Creek thrust of Whitebread (1994). Collections of conodonts from these strata range from Mississippian to Permian in age, and fusulinids are of Permian age (Whitebread, 1994). The random pattern of ages of these fossil collections suggests the presence either of unmapped faults or possibly of reworked conodonts. In any event, the age range of these beds as indicated by fossils, their lithic composition (especially the arkosic rocks), and the position of the beds adjacent to uncontested exposures of the Inskip suggest their original assignment to the Inskip Formation by Ferguson and others is reasonable; therefore, these beds are here reassigned to the Inskip Formation. However, for the purpose of discussion, this unit is shown in figure 2 as Havallah.

\section{Southern Exposures}

In the southern East Range, on both sides of Hot Spring Canyon, strata similar in lithic composition and general appearance to typical beds of the Inskip Formation originally were mapped by Muller and others (1951) as Inskip Formation. These same strata subsequently were designated Havallah by Johnson (1977) and by Stewart and Carlson (1978). Because the lower strata consist largely of arkosic rock and overlie the Valmy Formation concordantly, the original assignment to the Inskip Formation by Muller and others is reasonable; therefore, the strata are here reassigned to the Inskip Formation. As in the northern exposures, this unit, for the purpose of discussion, is shown in figure 2 as Havallah.

\section{Metamorphism}

The Inskip Formation was subjected to two phases of metamorphism: the first was at the time of deposition and the second was in the Jurassic or later. In the first phase, the plagioclase of the basaltic rocks was converted to albite by contact with seawater, and ferromagnesian minerals were altered to hornblende. Plagioclase of the felsites was also converted to albite. This process could be considered as alteration rather than metamorphism; but, by whatever name, the process produced a profound change in the mineralogy of the igneous rocks. While the sedimentary rocks do contain a small percentage of albite, their much more abundant K-feldspar apparently escaped unchanged. Albitized basalt and felsite were termed respectively spilite and keratophyre in older publications, and their origins were not understood.

In the second phase, most of the igneous and nearly all sedimentary rocks were mylonized by shearing stress parallel to bedding. (Note: In this report, the term "mylonize" is used rather than the equivalent "mylonitize." The equivalent textural term is flaser or flasered.) The intensity of mylonization varied according to the rock type and stratigraphic position. The more massive bodies of basalt and felsite appear to have been relatively resistant to the mylonizing process, and sedimentary strata of Permian age appear to have been relatively little affected compared with the more deeply buried Mississippian and Devonian rocks.

The superposition of the two phases of metamorphism complicates the assignment of the Inskip to established metamorphic facies. Neither the term greenschist facies nor the term amphibolite facies is strictly appropriate because the end product of alteration of the original basaltic components is albite, characteristic of the greenschist facies, and hornblende, characteristic of the amphibolite facies.

The age of the dynamic metamorphism is uncertain. Although the degree of metamorphism decreases upward, the Rochester Rhyolite, regarded as at least partly Triassic, is distinctly metamorphosed.

\section{Megastructures of the East Range}

In the East Range, detailed mapping by Whitebread (1994) indicates that Cambrian, Ordovician, and upper Paleozoic strata form an anticline that is overturned to the northwest. Separated from this anticline by a northwestverging reverse or thrust fault, upper Paleozoic and Triassic strata form a syncline also overturned to the northwest. If the folded strata in the East Range were to be restored to their original horizontal attitude, they would form a concordant stack in which an upright sequence of Cambrian and Ordovician age is overlain disconformably by an upright sequence of late Paleozoic and Triassic ages. The northwest vergence of folds and faults in the East Range may seem 


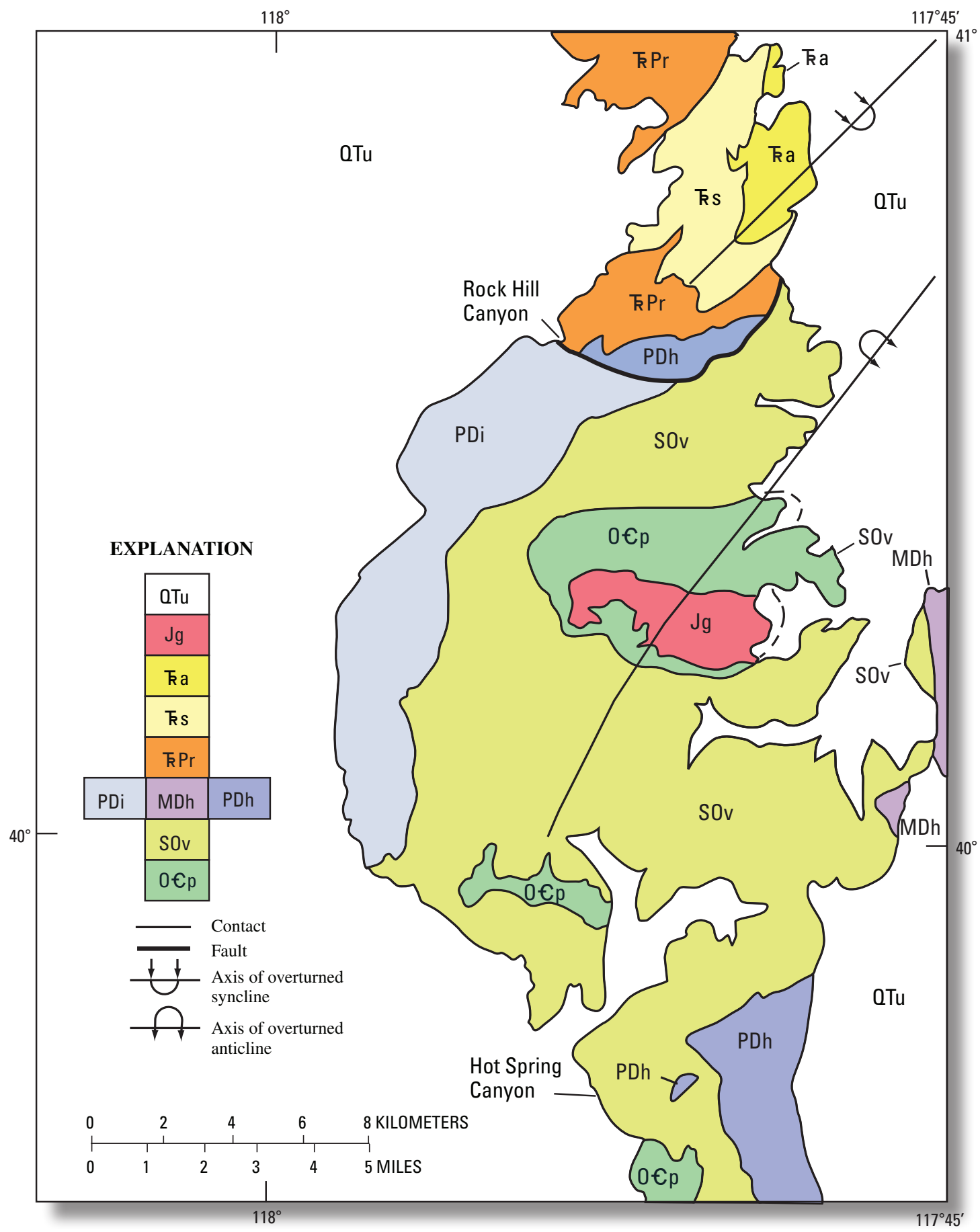

Figure 2. Central part of the East Range modified from Whitebread (1994), Whitebread and Sorensen (1983), and Johnson (1977). Paleozoic rocks form an anticline overturned to the west and northwest; Triassic rocks and a sliver of Paleozoic rocks form a syncline overturned to the northwest. The anticline and syncline are separated by a reverse or thrust fault. Strata of the anticline are: (1) the Cambrian to Lower Ordovician Preble Formation (O€p), (2) the Ordovician to lowest Silurian Valmy Formation (SOv), (3) the Upper Devonian to Permian Inskip Formation (PDi), (4) the Devonian to Mississippian Harmony Formation (MDh), and (5) Devonian to Permian Havallah sequence (PDh). Strata of the syncline are: (1) the Devonian to Permian Havallah sequence (PDh), (2) the Permian? to Triassic Rochester Rhyolite ( $\mathrm{kPr}$ ), (3) the Triassic Star Peak Group (ks), and (4) the Auld Lang Syne Group ( $\mathrm{k}$ a). Units labeled Harmony (MDh) and Havallah (PDh) on this and most published maps of the East Range are reassigned to the Inskip Formation in this report. Post-Triassic units are: Jurassic granitic rocks $(\mathrm{Jg})$ and Tertiary and Quaternary units undifferentiated (QTu). 
counterintuitive, but such structures in several areas of northwestern Nevada including the East and Hot Springs Ranges were recognized long ago (Wallace and Silberling, 1964) and more recently with respect to the Hot Springs Range (Jones, 1993).

\section{Petrologic Features of the Inskip Formation}

\section{Source of Data}

All samples pertaining to the Inskip Formation in this report are derived from strata universally assigned to the Inskip exposed between Rock Hill Canyon on the north and Hot Spring Canyon on the south. Many of the finer grained rocks cannot be identified in the field with certainty and require microscopic examination and $\mathrm{X}$-ray diffraction. Laboratory work was based on more than 150 thin sections, 150 whole-rock X-ray diffraction patterns, and 11 chemical analyses. The Inskip is extremely heterogeneous, and the photomicrographs shown in figures 3 to 10 are samples of the more common lithic types.

Almost all the arkosic rocks are in the lower part of the Inskip, most of the igneous bodies and quartzite are in the upper part, and all of the fine-grained, pure quartz rocks interpreted as metacherts are high in the upper part. Because the proportions of lithic types vary in the extreme, both laterally and stratigraphically within the Inskip, precise estimates of relative abundances have not been attempted.

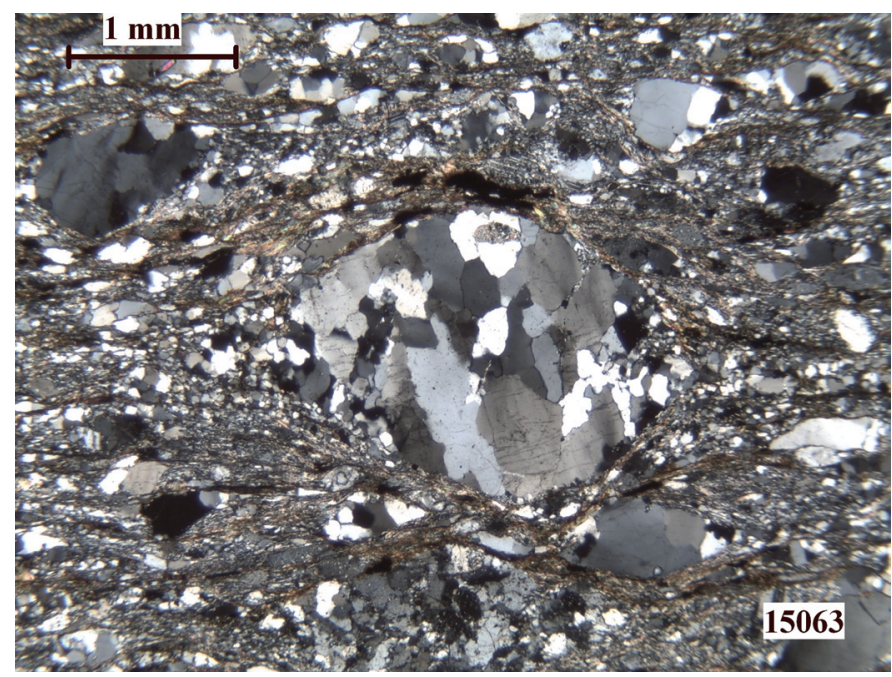

Figure 3. Sheared arkosic sandstone from the lower Inskip Formation. Clasts are quartz, quartzite, K-feldspar, and plagioclase. Megacrysts were abraded, and fine-grained quartz has crystallized syntectonically in pressure shadows. Crossed polarizers.

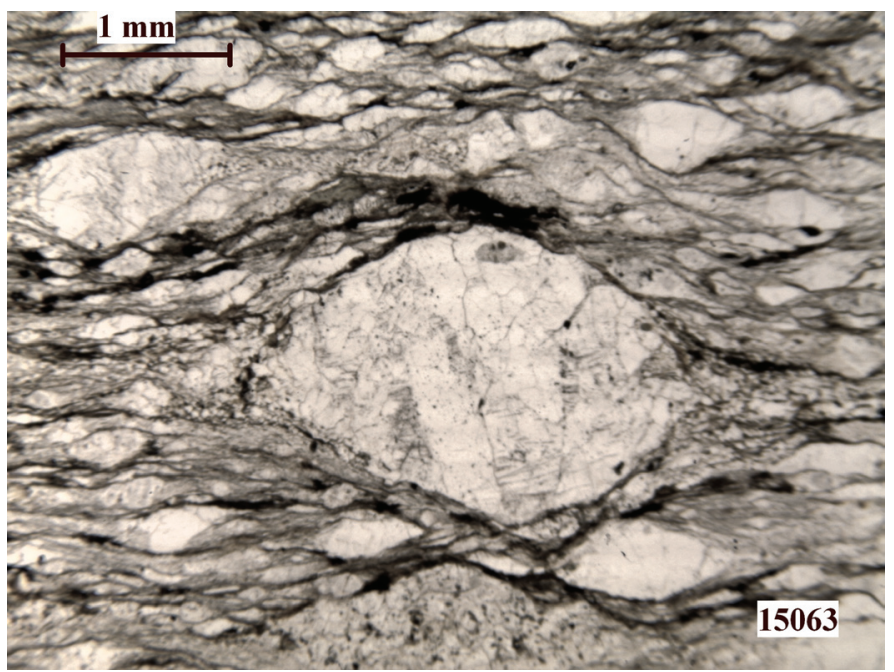

Figure 4. Unpolarized view of figure 3.

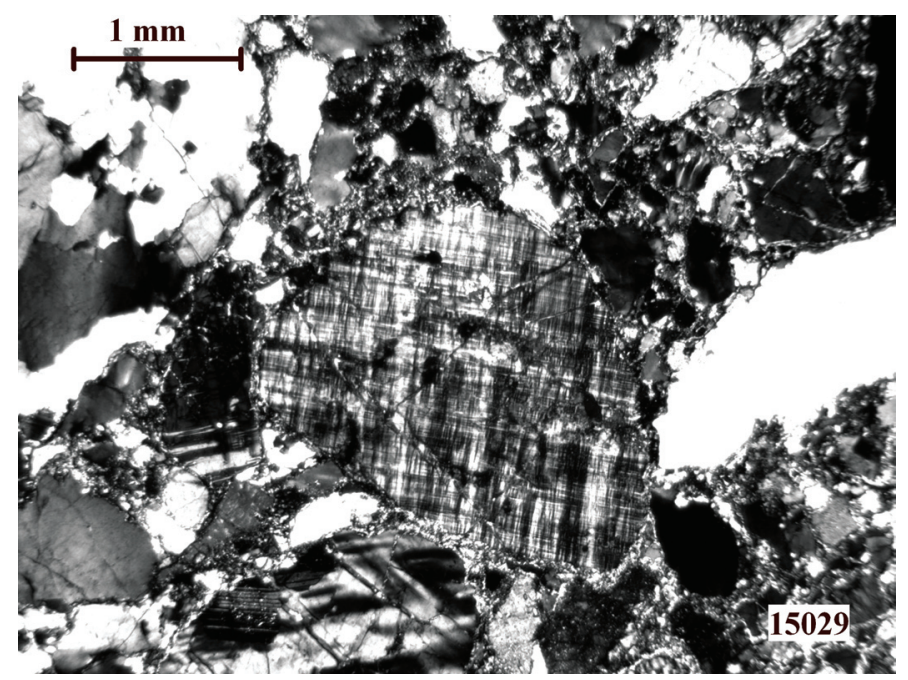

Figure 5. Coarse arkosic sandstone from a massive bed in the lower Inskip Formation. This specimen shows no evidence of shear. Crossed polarizers.

\section{Metasedimentary Rocks}

Interlayered beds of mylonized sandstone and conglomerate form much of the lower unit of the Inskip and a smaller part of the upper unit. Less common are limestone and inconspicuous, poorly exposed beds of siltstone and shale. Beds of sandstone range from a few centimeters to several meters in thickness. Most are tabular at the outcrop scale, but some have been deformed into lenses. The original thickness and internal features of the beds have been altered by beddingparallel mylonization, which affected some beds more than others. Some of the thicker beds that are relatively unaffected 


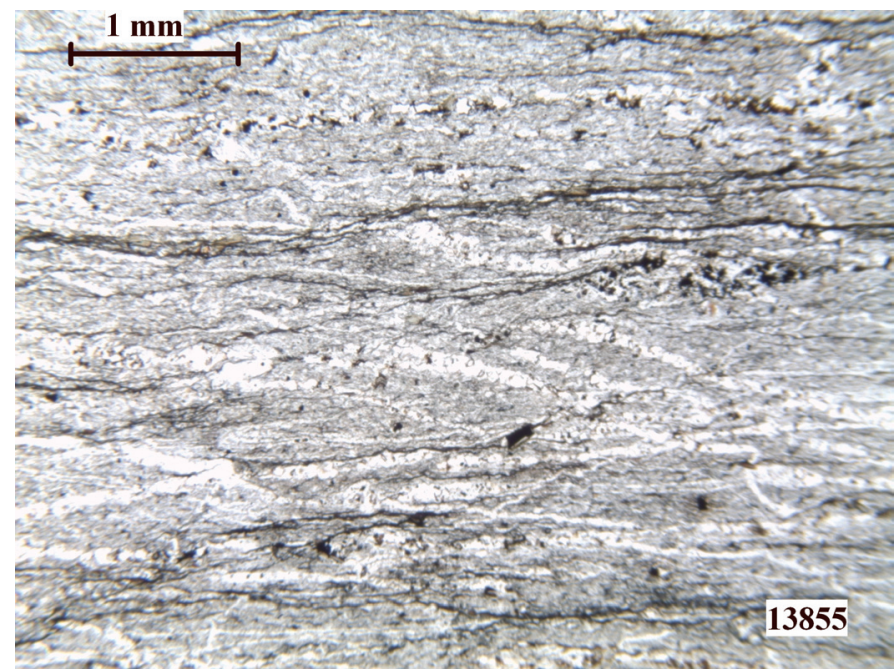

Figure 6. Chert from the uppermost part of the Inskip Formation. The carbon-rich stylolites are preserved in this specimen, and radiolarians are sporadically preserved in others. The only effect of the relatively slight metamorphism was to slightly increase the grain size. Unpolarized.

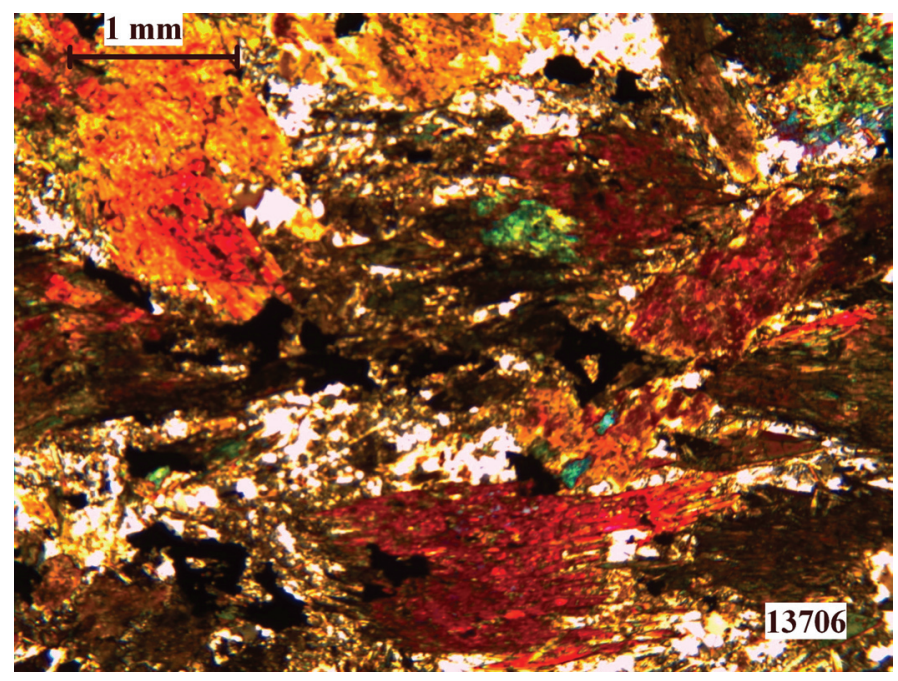

Figure 7. Metabasalt from the upper member of the Inskip Formation. Megacrysts are magnesian hornblende, groundmass is albite and ilmenite. This specimen shows slight evidence of shear. Crossed polarizers.

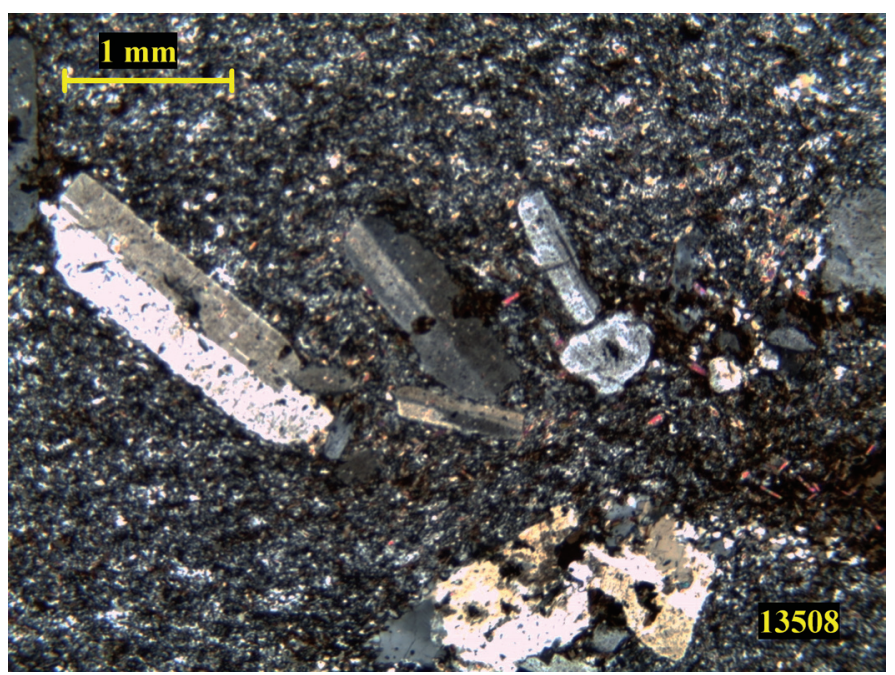

Figure 8. Relatively unsheared porphyritic felsite from the upper part of the Inskip Formation. Megacrysts are albite, groundmass is quartz and biotite. Crossed polarizers.

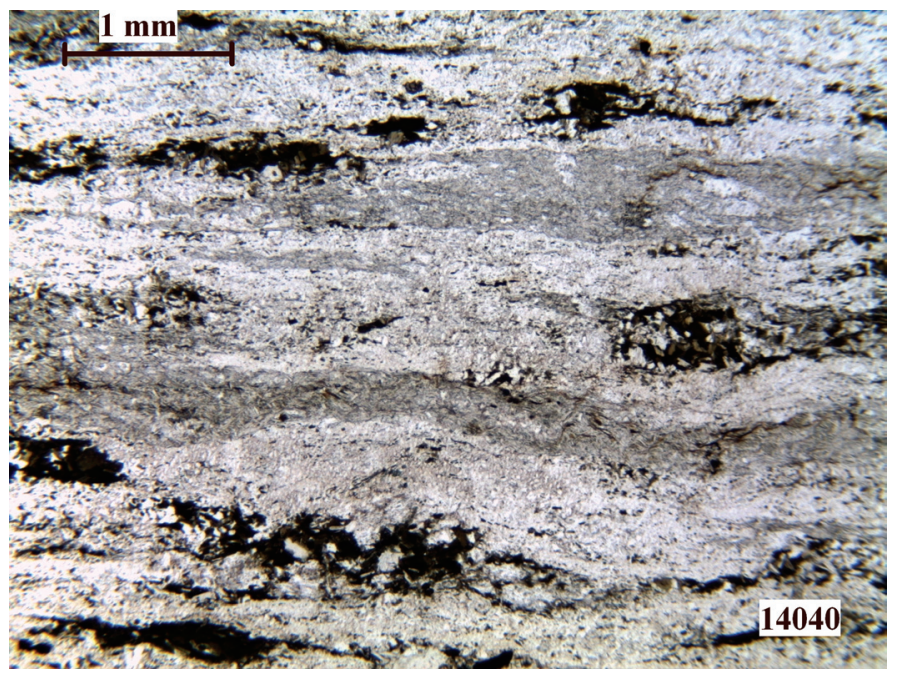

Figure 9. Sheared felsite from the lower part of the Inskip Formation. Light bands are albite and quartz, medium bands are muscovite, dark bands are biotite. Uncrossed polarizers. 


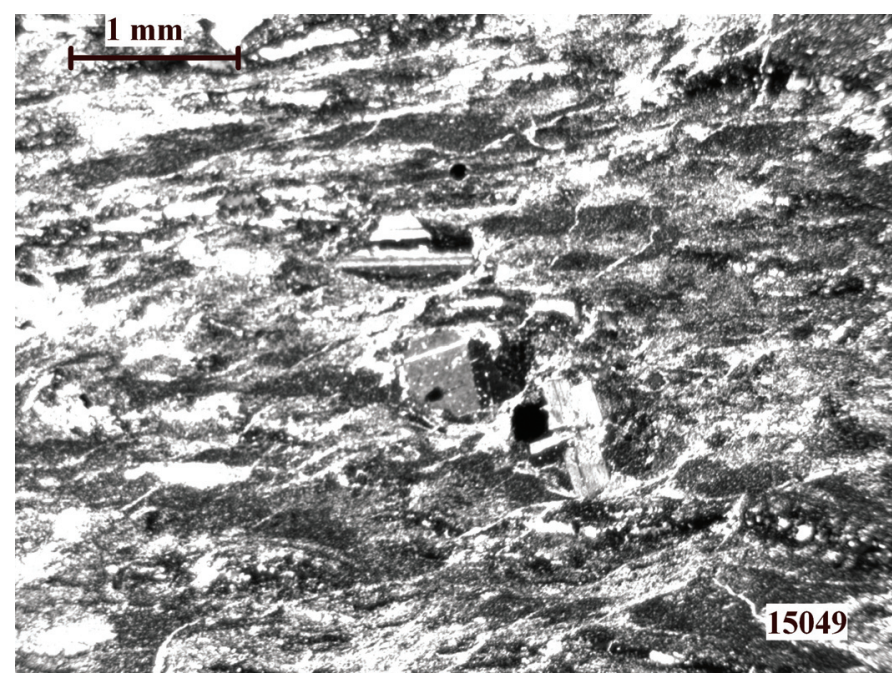

Figure 10. Sheared porphyritic felsite from the Rochester Rhyolite at the base of the Triassic sequence immediately overlying the Inskip Formation. Megacrysts are albite, groundmass is albite, quartz, and muscovite. Crossed polarizers.

by mylonization display graded bedding. Relatively thin beds commonly are strongly mylonized and have lost most of their original texture and sedimentary structure as a result of abrasion, recrystallization, and segregation of minerals into lenses. The relative thinness of the intensely mylonized beds may be an original feature, may be due to the mylonizing process, or, more likely, both. Clasts range from cobble size to fine sand size, rarely boulder size. The larger clasts are composed of quartzite, arkosic sandstone, and rarely chert, some of which display the faint outlines of radiolarians. The smaller clasts are quartz, quartzite, albite, K-feldspar, and mica, rarely chert, shale, and basalt (figs. 3-5). The cobble- and boulder-size clasts are elongated and flattened as a result of recrystallization under shearing stress. Many small pebbles and large sand grains appear, in thin section, to have been reduced in size by abrasion and are commonly rotated.

Some cobbles are composed of quartzite similar to that of the Valmy Formation, on which the Inskip lies. Boulders in intraformational conglomerate are composed of arkosic rock similar to arkosic sandstone beds of the Inskip. Much of the quartz of sand size and the chert clasts could have come from the Valmy Formation, but many quartz grains are much too large to have originated from the Valmy. Based on studies of thin sections of Valmy quartzite from many locations in Nevada, the quartz grains of that formation rarely exceed one millimeter in diameter (Ketner, 1966), whereas a major component of the Inskip consists of quartz grains that are several millimeters in diameter in spite of metamorphic size reduction. Some beds in the uppermost part of the Inskip may be weakly recrystallized cherts. These are composed wholly of fine sandsize quartz grains and, in spite of recrystallization, display stylolites like those typically present in bedded chert (fig. 6).
Such beds are stratigraphically close to limy beds that yielded Permian conodonts.

As described in subsequent sections, correlatives of the Inskip include olistostromes, mélanges, and very large limestone clasts. Such components may be present in the Inskip but have escaped notice because of the pervasive beddingparallel shearing. The effect of shearing would be to elongate such deposits to the point of making them resemble beds or lenses of more conventional sedimentary origin.

\section{Metaigneous Rocks}

Igneous rocks throughout the Inskip Formation range from fractions of one meter to several meters in thickness and are generally tabular and parallel to bedding, although some are of irregular shape. Some tabular layers transect bedding at the outcrop scale at very low angles, and some appear to have altered the sedimentary rocks above and below. Such bodies are clearly intrusives. Tabular bodies that do not appear to cut bedding and have not altered overlying beds are regarded as flows or possibly tuffs.

\section{Metabasalt}

Irregularly shaped bodies and tabular layers of basalt are present in the lower unit of the Inskip and are abundant in the upper unit. The tabular bodies, which are parallel or nearly parallel with bedding of intercalated sedimentary strata, range from a few centimeters to a few meters in thickness. The irregularly shaped bodies and thick tabular bodies display relatively little internal structure, but thin tabular bodies commonly display internal planar structure parallel with bedding. Pillow structures were not observed in any of the metabasalts, and deformed amygdules were observed in very few.

In thin sections of the basalts, the cataclastic texture characteristic of the sedimentary rocks is either relatively subtle or absent. Typically, slightly oriented blades, sheaves, and lenticular clusters of hornblende are embedded in a matrix of smaller, equant grains of albite (fig. 7). A few thin sections display good evidence of shear stress including boudinage, rotated clusters of hornblende, and pressure shadows adjacent to megacrysts.

Microscopic study and X-ray diffraction patterns indicate that the metabasalts consist almost entirely of albite and bluegreen, magnesian hornblende. Minor components are brown hornblende, biotite, epidote, sphene, ilmenite, and quartz. Pyroxene, olivine, K-feldspar, and plagioclase more calcic than albite are very scarce or absent. In some basalts, albite is more abundant than hornblende; in most, hornblende is dominant. Chemical analyses of a variety of basalts in the Inskip indicate a subalkaline basaltic composition (table 1), but these analyses may not accurately reflect the original compositions because the rocks have been subjected to metamorphic processes.

In the field, basaltic tabular bodies resemble some finegrained metasediments but can commonly be identified as 
Table 1. Chemical composition of metabasalt of the Inskip Formation, East Range, Nevada.

\begin{tabular}{lccccc}
\hline $\begin{array}{l}\text { Sample } \\
\text { number }\end{array}$ & $\mathbf{1 3 6 5 5}$ & $\mathbf{1 3 7 0 5}$ & $\mathbf{1 3 7 0 6}$ & $\mathbf{1 3 7 0 7}$ & $\mathbf{1 3 7 0 8}$ \\
\hline \multicolumn{5}{c}{ Major-oxide composition } \\
\hline $\mathrm{SiO}_{2}$ & 49.8 & 48.3 & 49.1 & 55.4 & 51.7 \\
$\mathrm{Al}_{2} \mathrm{O}_{3}$ & 15.2 & 16.0 & 14.3 & 11.8 & 17.0 \\
$\mathrm{FeTO}_{3}$ & 10.5 & 11.1 & 13.7 & 8.84 & 8.49 \\
$\mathrm{MgO}$ & 7.74 & 8.54 & 6.30 & 8.59 & 7.26 \\
$\mathrm{CaO}$ & 9.96 & 10.2 & 9.63 & 9.45 & 9.89 \\
$\mathrm{Na}$ & 3.24 & 2.65 & 2.93 & 2.96 & 3.43 \\
$\mathrm{~K}_{2} \mathrm{O}$ & 0.40 & 0.21 & 0.30 & 0.38 & 0.26 \\
$\mathrm{TiO}_{2}$ & 1.25 & 1.39 & 2.48 & 0.88 & 0.82 \\
$\mathrm{P}_{2} \mathrm{O}_{5}$ & 0.16 & 0.19 & 0.35 & 0.25 & 0.13 \\
$\mathrm{MnO}$ & 0.17 & 0.20 & 0.21 & 0.21 & 0.18 \\
$\mathrm{LOI}$ & 1.05 & 0.79 & 0.48 & 0.45 & 0.50 \\
\hline
\end{tabular}

${ }^{1}$ Method of analysis: WDXRF, weight percent.

\section{DESCRIPTION OF SAMPLES}

13655: fine-grained; magnesium-sodium hornblende, albite; flasered.

13705: coarse-grained; very massive; magnesium hornblende, albite; not flasered.

13706: coarse-grained; magnesium hornblende, albite, ilmenite; not flasered.

13707: fine-grained; magnesium hornblende, albite, biotite, quartz veins and amygdules; flasered.

13708: coarse-grained; magnesium hornblende, albite; flasered.

basalt by their somewhat greenish cast. The metabasalts must have originated as basaltic magma but were altered by contact with seawater either within saturated sediments or in the sea itself, in either event resulting in the complete alteration of calcic plagioclase to albite and mafic minerals to hornblende.

\section{Metafelsite}

The felsites are porphyritic, quartz-bearing rocks of igneous origin. Although some of these rock bodies are of irregular shape, most are tabular layers parallel, or nearly so, with beds of mylonized sedimentary rocks and tabular bodies of basalt. They are sparsely present in the lower part of the Inskip and abundant throughout the upper part.

The felsites are composed of quartz, albite, muscovite, and biotite as determined microscopically and by wholerock X-ray diffraction (fig. 8). Scattered opaque minerals, including ilmenite, and a trace of microcline are present in some of them. The megacrysts are albite; none is quartz although exsolved quartz blebs are common in the albite. Microscopic examination and X-ray diffraction patterns of the fine-grained matrix indicate it is composed largely of quartz. Texture varies from unflasered porphyry of thick bodies that have large, notably sericitized, subhedral albite megacrysts to the relatively equigranular mylonites in which the megacrysts have been rotated, reduced to small lenses, or almost completely destroyed (fig. 9). In these, the biotite is commonly segregated into thin lenses. The mineralogical composition indicates they have been albitized, presumably by contact with seawater, either within saturated sediments or in the sea itself. The chemical composition of the felsites suggests they are of rhyolitic to andesitic origin (table 2).

In the field, tabular felsite bodies can be mistaken for mylonized sandstone beds. Microscopically, however, the felsites differ from sandstones in the presence of intensely sericitized albite megacrysts, in the absence of quartz megacrysts, in the relative abundance of biotite that is commonly segregated into thin lenses, and in the near absence of K-feldspar.

\section{The Felsite Problem}

In the East Range, felsite bodies are in beds ranging from Mississippian to Triassic in age. Were they intruded into saturated sediments or erupted on the sea floor contemporaneously with deposition of the enclosing sediments, or were they intruded into consolidated Paleozoic rocks in Triassic time? The irregular bodies, some of which do not display evidence of shear, probably are intrusives too massive to have been mylonized. The tabular layers, some of which are as thin as a few centimeters, may represent original sills, flows, or tuffs, their thinness partly due to the metamorphic process. The abundance of quartz and albite together with the near absence of K-feldspar suggest that these rocks may have originated as rhyolitic, dacitic, or andesitic magma but that K-feldspar, oligoclase, and andesine were altered to albite by contact with seawater.

Triassic formations of the East Range are mainly sedimentary rocks. However, the basal unit of the Triassic sequence is the Rochester Rhyolite, a member of the Koipato Group, which sits disconformably on uppermost beds of the Inskip. The Rochester, at this location, is undated and may be partly of Permian age. An X-ray diffraction pattern and thin sections from the Rochester indicate that this rock is flasered and is composed of quartz and muscovite, with sericitized albite megacrysts - practically the same texture and mineral composition as that of the felsitic rocks in the underlying Inskip Formation (fig. 10). The chemical composition is also similar. Conceivably, the Rochester Rhyolite and the felsites of the Inskip are all intrusives of latest Permian to Early Triassic age, but this would not account for the universally albitic composition of their feldspars, which implies direct contact with seawater. Tentatively, the Inskip bodies and the Rochester Rhyolite are interpreted to be contemporaneous with the sedimentary rocks with which they are interlayered. If this interpretation is correct, basalt and felsite emplacement alternated frequently from Late Devonian to Early Triassic time. 
Table 2. Chemical composition of metafelsites of the Inskip Formation and the Triassic Rochester Rhyolite, East Range.

\begin{tabular}{lcccccc}
\hline $\begin{array}{c}\text { Sample } \\
\text { number } \\
\text { Formation }\end{array}$ & $\begin{array}{c}\mathbf{1 3 6 4 9} \\
\text { Inskip } \\
\text { Formation }\end{array}$ & $\begin{array}{c}\mathbf{1 3 6 5 2} \\
\text { Inskip } \\
\text { Formation }\end{array}$ & $\begin{array}{c}\mathbf{1 3 6 5 6} \\
\text { Inskip } \\
\text { Formation }\end{array}$ & $\begin{array}{c}\mathbf{1 3 7 8 0} \\
\text { Inskip } \\
\text { Formation }\end{array}$ & $\begin{array}{c}\mathbf{1 4 0 4 0} \\
\text { Inskip } \\
\text { Formation }\end{array}$ & $\begin{array}{c}\text { 15049 } \\
\text { Rochester } \\
\text { Rhyolite }\end{array}$ \\
\hline $\mathrm{SiO}_{2}$ & 69.4 & 66.3 & 64.1 & 60.4 & 65.5 & 69.4 \\
$\mathrm{Al}_{2} \mathrm{O}_{3}$ & 14.2 & 14.4 & 15.3 & 15.3 & 14.5 & 14.1 \\
$\mathrm{FeTO}_{3}$ & 01.70 & 02.97 & 04.66 & 06.65 & 03.48 & 1.92 \\
$\mathrm{MgO}$ & 00.17 & 00.42 & 01.90 & 02.77 & 00.84 & 0.23 \\
$\mathrm{CaO}$ & 01.30 & 01.33 & 01.37 & 04.89 & 02.02 & 0.11 \\
$\mathrm{Na}_{2} \mathrm{O}$ & 03.78 & 03.93 & 04.49 & 02.55 & 04.12 & 3.21 \\
$\mathrm{~K}_{2} \mathrm{O}$ & 03.93 & 03.44 & 03.72 & 03.09 & 02.86 & 5.08 \\
$\mathrm{TiO}_{2}$ & 00.25 & 00.27 & 00.57 & 01.12 & 00.40 & 0.16 \\
$\mathrm{P}_{2} \mathrm{O}_{5}$ & 00.04 & 00.08 & 00.14 & 00.23 & 00.12 & 0.04 \\
\hline
\end{tabular}

${ }^{1}$ Method of analysis: ICP-AES, weight percent.

\section{DESCRIPTION OF SAMPLES}

13649: interlayered with limestone; quartz, albite, muscovite; flasered; equigranular; x-ray diffraction pattern identical to that of 15049 .

13652: interlayered with conglomerate; quartz, albite, muscovite, biotite; flasered; equigranular.

13656: interlayered with arkosic sandstone; quartz, albite, much biotite; flasered; prominent feldspar megacrysts.

13780: cuts bedding at small angle; quartz, albite, much biotite; variably flasered; prominent feldspar megacrysts; amygdules.

14040: quartz, albite, muscovite; intensely flasered; prominent feldspar megacrysts.

15049: Rochester Rhyolite at base of Triassic sequence; quartz, albite, much muscovite; flasered; rotated megacrysts; X-ray diffraction pattern identical to that of 13649.

\section{Depositional Conditions of the Inskip}

The Inskip was deposited in a marine environment under conditions that varied from time to time throughout its long history. The graded bedding observed in some exposures of the sedimentary rocks suggests deposition by turbidity currents, but most sedimentary structures have been obliterated by metamorphic processes. The large size of most of the clasts, including boulders in intraformational conglomerate, indicates proximity to sources. Feldspathic and large quartz clasts must have been derived from a nearby granitic terrane, and other components probably were derived from sources such as the Valmy Formation exposed to the east (Ketner and others, 2005). The presence of intraformational conglomerate composed of feldspathic sandstone clasts low in the Inskip suggests tectonic instability and intervals of elevation and erosion within the depositional basin. An additional indication of tectonic instability is the presence of cobbles and even boulders of arkosic rock in Lower Mississippian strata of eastern Nevada. These, by their petrographic features as revealed in numerous thin sections, were derived from the Inskip or other arkosic rocks in northwestern Nevada. The picture that emerges is of a vertically oscillating basin or trough, bound on the west by granitic highlands and on the east by highlands composed of Paleozoic siliceous rocks such as the Valmy Formation, as discussed by Ketner and others (2005).

\section{Hot Springs Range}

Although they have been structurally disrupted, the Paleozoic stratigraphic components of other ranges in the arkosic triangle are similar to those of the East Range. Starting with the Hot Springs Range, stratigraphic and structural issues pertaining to these ranges are discussed in the following sections for the purpose of establishing the hypothesis that all Upper Devonian to Permian units in the arkosic triangle, by whatever name, are parts of a single genetic assemblage, deposited on a similar substrate, in a single depositional basin, and have the same tectonic history.

\section{Source of Data}

The Hot Springs Range, $80 \mathrm{~km}$ northeast of the East Range (fig. 11), was mapped in detail by Jones (1991a). 


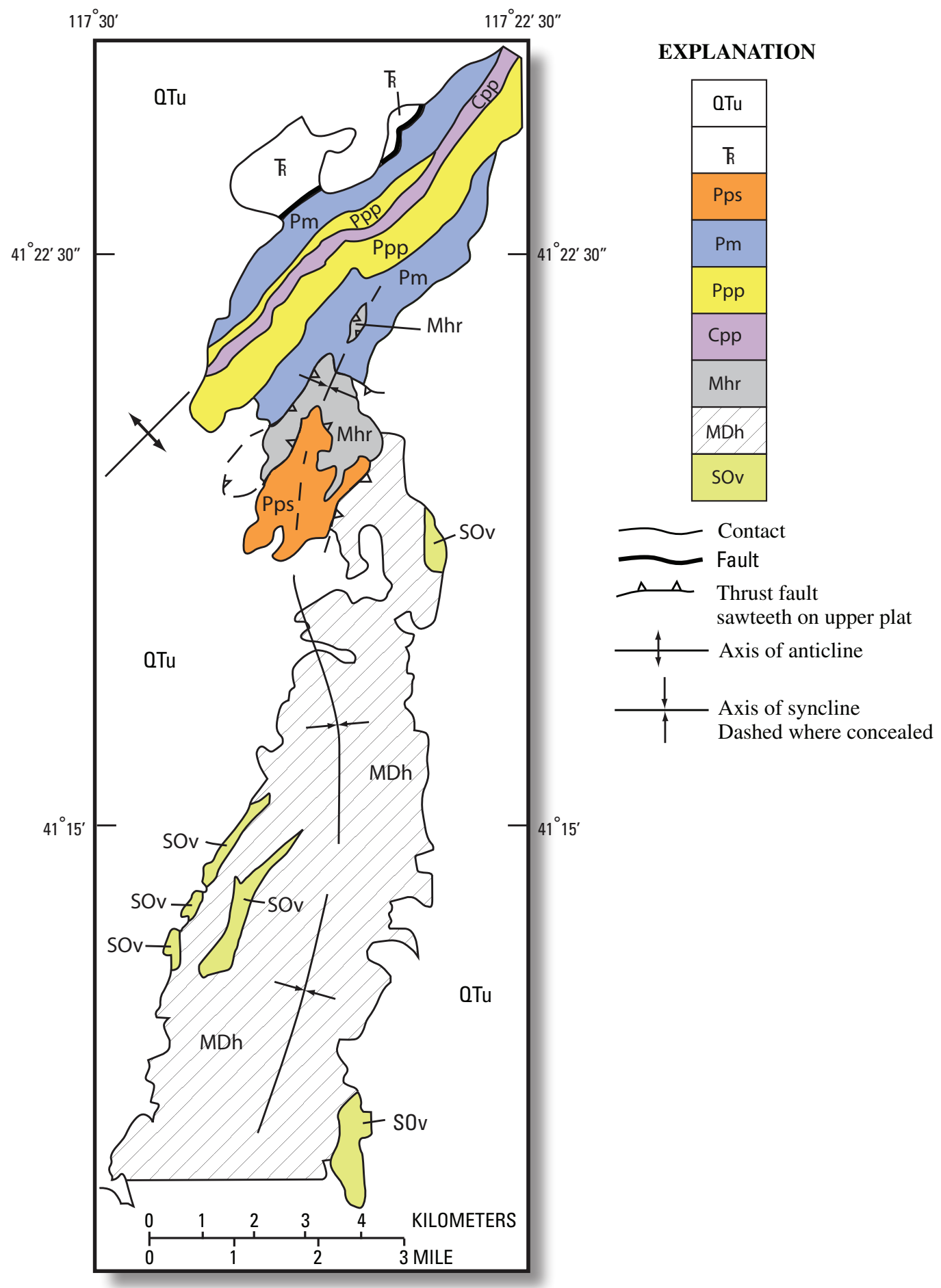

Figure 11. Generalized and simplified map of part of the Hot Springs Range modified from Jones (1997a, b) showing the Hot Springs Range syncline and the northern Hot Springs Range anticline. Strata of the syncline are (from oldest to youngest): the lowest Silurian and Ordovician Valmy Formation (SOv), the Harmony Formation (MDh), and the Home Ranch subterrane (Mhr). Areas shown as Valmy Formation on the west and northeast sides of the range may include some Harmony limestone. Strata of the anticline are (from oldest to youngest): the carboniferous lower Poverty Peak subterrane (Cpp), the Permian upper Poverty Peak subterrane (Ppp), the Permian Poverty Peak-Golconda mélange (Pm), the Permian Phyllite and shale subterrane (Pps), and the Triassic and Jurassic (?) Jungo terrane ( $\mathrm{k}$ ). Post-Triassic strata are Tertiary and Quaternary units undifferentiated (OTu). 
Except for the Valmy and Harmony Formations, my knowledge of that range is based entirely on her published work (Jones, 1991b, 1993, 1997a, b), discussions with her, and on thin sections of rocks that she lent me. Her interpretation of the structure that the various formations were brought together tectonically from differing environments is entirely plausible. However, as a result of my study of the East Range, I here offer an alternative theory: that the formations of the Hot Springs Range, prior to faulting, formed an intact stratigraphic sequence similar to that of the East Range.

The East Range and Hot Springs Range exhibit similar stratigraphic, petrologic, and structural features. Both ranges lie at the western margin of the Paleozoic miogeocline. In both ranges the exposed strata range from lower Paleozoic to Triassic. In both, most of the Silurian and Devonian systems are missing. In both, the middle Paleozoic strata are notably arkosic and the upper Paleozoic strata are rich in basalt, felsite, and chert. In both, as here interpreted, two large northeasttrending, northwest-vergent folds are separated by northwestvergent faults. In the following sections the tectonostratigraphic units recognized by Jones (1997a,b) are briefly described in stratigraphic order from older to younger.

\section{Strata in the Hot Springs Range Underlying the Inskip-Equivalent Rocks}

In this section, the generally accepted stratigraphy and Cambrian age of the Paradise Valley Chert are radically reinterpreted on the basis of local and regional relations. The Ordovician Valmy Formation and the overlying Paradise Valley Chert, as here interpreted, concordantly underlie Inskipequivalent strata of the Hot Springs Range and constitute the oldest exposed rocks of the Hot Springs Range syncline.

Since it was first described, the Paradise Valley Chert of the Hot Springs Range has been considered to be of Cambrian age (Hotz and Willden, 1964). The formation, as described by Hotz and Willden and by Jones (1997a, b), consists of two lithic units: chert and limestone. Trilobite fragments and conodonts extracted from the limestone unit indicate a Cambrian age, but the chert unit is not directly dated and its age could be different from that of the limestone. Complex structure and poor exposures have resulted in uncertainty as to the stratigraphic relations of the limestone and chert beds to each other and to overlying and underlying units. In the present interpretation based on observed field relations, the limestone unit of the Paradise Valley Chert is part of the Harmony Formation. The chert part of the Paradise Valley Chert, where it is well exposed on the west side of the range, is quite distinctive, being composed of a lower black chert unit and an upper mineralized white chert unit. As here interpreted, this chert couplet is equivalent to the "chert couplet of Table Mountain" in the East Range. This couplet is at the top of the Valmy Formation in the East Range (Ketner and others, 2000) and in numerous exposures across Nevada. In the northern Adobe Range of northeastern Nevada, the chert couplet was determined, by means of contained graptolites and radiolarians (Ketner and Ross, 1990; Ketner, 1991; Noble and others, 1997), to be close to the Ordovician-Silurian boundary in age and probably straddles that border. In subsequent discussions, the term Valmy Formation includes the chert part of the Paradise Valley Chert.

\section{Stratigraphic Units Equivalent to the Inskip in Age and General Aspect}

In the following paragraphs the tectonostratigraphic units of Jones (1997b) are treated as stratigraphic units, essentially formations, and described from oldest to youngest. If, as here interpreted, the upper Paleozoic rocks of the Hot Springs Range are parts of a formerly intact stratigraphic sequence comparable to the Inskip Formation, the various depositional environments indicated by its components represent changing tectonic conditions through time.

\section{Harmony Formation}

The Harmony Formation, composed of mainly coarsegrained arkosic sandstone and lesser amounts of calcarenite and shale, is of Late Devonian to Mississippian age and is therefore similar to, and correlative with, the lower, arkosic part of the Inskip Formation. A detailed description was given in Jones (1997a, b), and its age was discussed in Ketner and others (2005), and Crafford (2007).

\section{Home Ranch Subterrane}

This unit, composed of mafic and felsic volcanic rocks, limestone, and chert, is of Mississippian age (Jones, 1997a, b). As such, it is equivalent to strata just above the arkosic part of the Inskip Formation, and it constitutes the youngest stratigraphic unit of the Hot Springs Range syncline.

\section{Lower Poverty Peak Sequence}

This unit, largely chert and basalt, is of Carboniferous age and, prior to faulting, overlay the Home Ranch subterrane. It is the oldest unit in the northern Hot Springs Range anticline.

\section{Upper Poverty Peak Sequence}

This unit of principally sedimentary rocks contains Permian conodonts and is exposed in two parallel belts overlying the Lower Poverty Peak sequence on the northern Hot Springs Range anticline. 


\section{Poverty Peak-Golconda Mélange}

The two Permian mélanges of Jones (1997b) are here combined into a single stratigraphic unit slightly younger than, and overlying, the Upper Poverty Peak sequence. Although the two mélanges differ in components of blocks, this difference could represent spatial variation within a single unit and is so interpreted here. The mélange is exposed in two parallel belts, one on each flank of the northern Hot Springs Range anticline. Mélanges were not identified in the Inskip Formation, but if present, they would be hard to identify as such because of the pervasive dynamic metamorphism.

\section{Phyllite and Shale Sequence}

This unit is the stratigraphically highest Paleozoic unit. It is exposed only on the south flank of the northern Hot Springs Range anticline, presumably because on the north flank it was cut out by the fault that separates Paleozoic from Triassic rocks. The notable chert content of this unit allies it with metachert beds in the uppermost part of the Inskip Formation.

\section{Triassic and Jurassic Rocks}

Triassic and Jurassic stratigraphic units of shelf and basin facies, isolated from the Paleozoic rocks by a fault, are equivalent to some of the Triassic and Jurassic shelf and basin units overlying the Inskip Formation. The Rochester Rhyolite, or equivalent felsic rock normally at the base of the Triassic sequence regionally, is not exposed, probably owing to this fault.

\section{Megastructures of the Hot Springs Range}

The Paleozoic rocks of the Hot Springs Range are here interpreted as a once-coherent stratigraphic sequence similar to that of East Range but one that has been dismembered by high- and low-angle faults of small displacement. As depicted in figure 11, the Valmy Formation, the Harmony Formation, and the Home Ranch subterrane form a broad syncline or synclinorium. The Poverty Peak subterrane, the Golconda and Poverty Peak mélanges, and the phyllite-shale unit form a nearly isoclinal anticline. The syncline and anticline are separated by a northwest-directed thrust fault. This thrust fault, as mapped by Jones (1997a) and as here interpreted, places the Home Ranch Formation of the syncline over the phylliteshale and mélange units on the southeast limb of the anticline. Therefore, as here interpreted, the East Range and the Hot Springs Range are similarly constructed of northeast-trending folds separated by west-vergent thrust faults, but the older strata of the Hot Springs Range form a syncline rather than an anticline as in the East Range, and the younger strata form an anticline rather than a syncline.

\section{Osgood Mountains}

The Osgood Mountains are about $100 \mathrm{~km}$ northeast of the East Range and just east of the Hot Springs Range. Cambrian and Ordovician rocks and formations that appear to be contemporaneous with the Inskip Formation are present in highly faulted relations to one another. Formations correlative with the Inskip include units named Harmony, Goughs Canyon, Farrel Canyon, and Adam Peak Formations (Hotz and Willden, 1964). McCollum and McCollum (1991) contributed much valuable data on the Osgood Mountains, but further work is required to settle persistent stratigraphic and structural problems.

\section{Sonoma Range}

The Sonoma Range is adjacent to the East Range on the east and northeast. The highly dismembered stratigraphic components of the Sonoma Range generally resemble the stratigraphic sequence of the East Range. As reconstructed here, the Harmony Formation and the Havallah sequence, which together correlate with the Inskip Formation, are underlain by Cambrian, Ordovician, and lowest Silurian strata similar to strata in the East Range and are overlain by Triassic rocks similar to those of the East Range.

\section{Stratigraphic and Structural Issues}

The oldest strata in the Sonoma Range, as in the East Range, are the mainly Cambrian Preble Formation and the mainly Ordovician Valmy Formation. Although separated by faults, they are here assumed to have been in normal stratigraphic sequence originally, as they are in the East Range. As interpreted by Gilluly (1967), who mapped much of the range in considerable detail, the Harmony Formation is of Cambrian age and therefore normally would underlie the mainly Ordovician Valmy Formation. As mapped, contact relations between these two units in many areas unequivocally place the Harmony above the Valmy. This was confirmed by my detailed observations in Bacon Canyon in the southern part of Gilluly's map area. In Bacon Canyon, arkosic strata clearly overlie the uppermost beds of the Valmy Formation with a concordant contact. To accommodate the seeming reversal of normal stratigraphic order, Gilluly separated the two units with a thrust fault, the "Clear Creek thrust." In the present interpretation, the Harmony is of latest Devonian to Mississippian age, partly based on lithic correlation with dated beds in the East Range and Hot Springs Range and partly on conodonts collected from a mass of limestone embedded in arkosic rocks of the Harmony Formation as mapped by Silberling (1975). Therefore there is no need for a thrust fault separating the Valmy from the Harmony, nor is there any physical evidence to support the concept. 
The simplest interpretation is that they form a normal, disconformable, depositional sequence, as the true age of the Harmony permits, and as contact relations in Bacon Canyon and in the East Range indicate. It should be noted that Gilluly (1967) apparently assigned coarse-grained arkosic sequences conspicuously interlayered with greenstone to the Valmy Formation, whereas he assigned coarse-grained arkosic sequences without interlayered greenstone to the Harmony Formation. This is inconsistent with mapping elsewhere; the lower part of the Inskip Formation in the East Range and the Harmony Formation of Battle Mountain include both arkosic rocks and greenstone.

\section{Havallah Sequence}

The Havallah sequence, present in the southern part of the Sonoma Range and which correlates with the upper parts of the Inskip Formation, is discussed in a subsequent section on the relation of the Inskip and the Harmony Formation to the Havallah Sequence.

\section{Triassic Rocks}

Similar Triassic formations are present in both the East Range and Sonoma Range. In both ranges they form northwest-vergent synclines (Gilluly, 1967; Whitebread, 1994).

\section{Battle Mountain}

Battle Mountain lies about $65 \mathrm{~km}$ east of the East Range. As originally interpreted by Roberts (1964), the Paleozoic stratigraphy bears little resemblance to that of the East Range. However, recent revisions of the ages of important units and their relations to each other, as here interpreted, bring the stratigraphy of the two areas much closer together. More detailed descriptions of the formations are given by Roberts (1964) and by Doebrich (1994).

\section{North Slope}

On the north slope of Battle Mountain, the "Cambrian" Harmony Formation is mainly underlain by the Valmy Formation and less extensively by Devonian chert (Theodore, 1994). Where the contact is fairly well exposed, it does not appear to be significantly angular. The Valmy consists of quartzite, shale, chert, and greenstone. Here, as elsewhere, the Harmony consists mainly of arkosic sandstone. The contact between the Harmony and the Ordovician and Devonian rocks was mapped originally by Roberts (1964) and subsequently by Theodore (1994) as the Dewitt thrust fault. This was logical because the relation appeared to be one of older strata superposed on younger strata. The Harmony is undated in the Battle Mountain area, but because it correlates lithically with Late Devonian to Mississippian parts of the Inskip Formation in the East Range and with the latest Devonian to Mississippian Harmony Formation of the Hot Springs Range, its age is here assumed to be within the latest Devonian to Mississippian range. This permits the interpretation that the lower contact of the Harmony Formation is depositional and not a fault.

\section{South Slope}

On the south slope of Battle Mountain, contacts in relation to topography clearly indicate that the Harmony Formation is underlain by heterogeneous strata assigned to the "Cambrian" Scott Canyon Formation (Doebrich, 1994). These strata include quartzite, shale, chert, and greenstone, all of which are similar to strata of the Valmy Formation as exposed on the north side of Battle Mountain. In addition, olistostromes are present sporadically just below the Harmony Formation (McCollum and others, 1985; Doebrich, 1994).

Ordovician conodonts identified by John Repetski were collected from two localities in the Scott Canyon Formation (McCollum and others, 1987), and Devonian radiolarians were obtained from chert beds at two locations (Jones and Wrucke, 1978; Murchey, in Theodore, 1994). Cambrian archaeocyathids and trilobites were obtained from limestone clasts in some of the olistostromes (Roberts, 1964; McCollum and others, 1985; DeBrenne and others, 1990). The dimensions of some of these clasts are several meters. The quartzite, shale, and greenstone components of the Scott Canyon are not dated by fossils. However, the quartzite strata are lithically identical to quartzite strata of the Valmy Formation and were mapped as Valmy by Roberts (1964). The general lithic aspect and paleontological data indicate that a large part, if not most, of the Scott Canyon should be assigned to the Valmy Formation. An unknown portion of the chert is of Devonian age and could be regarded as the oldest component of the heterogeneous Harmony Formation and as only locally present at the base of that unit. In addition to the chert deposits, the olistostromes are here considered to be basal components of the Harmony Formation for two reasons: (1) they consistently occur just below arkosic strata of the Harmony, and (2) limestone olistoliths of Cambrian age are present near the base of the Harmony Formation in the Hot Springs Range (Ketner and others, 2005). The archaeocyathids in these olistostromes have been intensively studied by DeBrenne and others (1990). These authors state that some of the forms "****suggest a paleogeographic relationship with northwestern Canada***" and other areas extremely remote from Nevada. This information led McCollum and McCollum (1989) to the conclusion that the Antler orogeny was "a transpressional orogen within a transcurrent fault system" and it tends to confirm the conclusion of Ketner and others (2005) and Crafford (2008), based entirely on other data, that the provenance of Cambrian limestone olistoliths, as well as arkosic clasts of the Harmony Formation, was an exotic 
terrane transported tectonically to Nevada from northwestern Canada. Olistostromes bearing large clasts of limestone were not identified in the Inskip Formation. However, some lenses of limestone observed in the Inskip may actually be such clasts, elongated by the dynamic metamorphism to the point of resembling normally deposited strata or lenses.

\section{The Havallah Sequence}

These upper Paleozoic rocks in fault contact with lower to middle Paleozoic strata on the west side of Battle Mountain are discussed in a subsequent section on the relation of the Inskip and the Harmony Formation to the Havallah Sequence.

\section{Unconformities}

The disconformity, or unconformity with only slight angular discordance, between the Valmy and the Harmony Formations represents the Antler orogeny currently defined as a Late Devonian to Early Mississippian event. A younger unconformity is present in the same area: the Battle Conglomerate of mid-Pennsylvanian age lies with angular unconformity on the Valmy and Harmony Formations, thus recording an event of folding or tilt, uplift, erosion, and a return to deposition of post-Harmony and pre-Battle age. This unconformity commonly has been regarded as evidence of the Antler orogeny, but because the Harmony is Late Devonian to Mississippian in age, it represents a distinctly younger tectonic event, the Humboldt orogeny of mid-Pennsylvanian age.

\section{Relation of the Inskip and the Harmony Formations to the Havallah Sequence in the Arkosic Triangle}

The Havallah sequence, which crops out in several mountain ranges of the arkosic triangle, is a series of mainly deepwater deposits ranging from Late Devonian to Permian in age and is therefore correlative with the Inskip Formation. This discussion argues that the Havallah is similar to the Inskip in general lithic composition and that it is part of the same genetic assemblage as the Inskip and the upper Paleozoic rocks of the Hot Springs Range, in agreement with Crafford (2007).

On maps dated in the 1950s, certain upper Paleozoic, relatively deepwater strata were divided between the mostly sedimentary Havallah Formation and the largely igneous Pumpernickel Formation. Now both units are subsumed under the name Havallah sequence, as detailed by Stewart and others (1977, 1986), and are commonly considered to be a major component of the Golconda allochthon or Golconda terrane.

The Inskip Formation is lithically comparable to, and correlative with, the Havallah sequence as now defined. Muller and others (1951) stated in their original description of the type occurrences of both the Havallah and Inskip Formations, that the Inskip is “***assumed equivalent to Havallah***" and “***may represent marginal facies of the more widespread Havallah." It would have been more accurate to say that the Inskip may represent a facies of the combined Havallah and Pumpernickel. Jones (1997a) applied the term Golconda terrane to middle to upper Paleozoic rocks of the Hot Springs Range, suggesting that they also are comparable to the Havallah as now defined. As interpreted here, the Inskip and the middle to upper Paleozoic rocks of the Hot Springs Range do, indeed, constitute a facies of the Havallah sequence because: (1) they occur close to the principal exposures of the Havallah; (2) like the Havallah, both sequences range from Late Devonian to Permian in age; (3) like the Havallah, both are predominantly deepwater deposits; (4) like the Havallah, both include igneous bodies of basaltic and felsic composition; and (5) like the Havallah, both are overlain by Triassic rocks.

Most exposures of the Havallah sequence do not include arkosic rocks, but in the southern East Range, an extensive area designated as Havallah on most published maps (for example, Johnson, 1977) includes basal arkosic strata disconformable on the Valmy Formation. In the Sonoma Range, the basal unit of the Havallah termed the "clastic unit of the Havallah sequence" by Silberling (1975) is, for the Havallah, an unusually coarse-grained sandstone and includes a small percentage of feldspar. The lack of arkosic deposits in other exposures of the Havallah could be due to incomplete exposure (most exposures of the Havallah are of the Pennsylvanian and Permian parts of the sequence), to nondeposition due to topographic relief in the depositional basin, to distance from the western source area, or to structural elimination during thrust faulting. In the present interpretation, the Inskip, upper Paleozoic rocks of the Hot Springs Range and sequences designated by various modern authors as Havallah constitute a genetically related assemblage that was deposited in the same basin, on the same substrate (the Valmy Formation), and was overlain by similar sequences of Triassic rocks.

\section{Sonoma Orogeny and Golconda Thrust}

For many years, contact relations near the boundary between Permian and Triassic rocks of the arkosic triangle have been interpreted as representing an orogenic event known as the Sonoma orogeny, and a thrust fault juxtaposing upper Paleozoic rocks of different facies has been known as the Golconda thrust (Silberling and Roberts, 1962). The relation between the "orogeny" and the thrust is uncertain; they could be the same age and genetically related, or the thrust could be younger.

The purposes of this discussion are to propose downgrading the Sonoma orogeny to a relatively minor tectonic event and to propose establishing the age of the Golconda thrust as Jurassic rather than Late Permian or Early Triassic. The result, to the extent it is successful, would be to unify the tectonic 
histories of the various mountain ranges in the arkosic triangle and reconcile the tectonic history of the area with modern field observations.

Although the contact between the Havallah and overlying volcanic rocks at the base of the Triassic sequence has been asserted to be a major unconformity representing the Sonoma orogeny in numerous publications, clear evidence supporting that concept in the form of detailed maps or descriptions of the contact is scarce. Maps by Ferguson and others (1952) and Muller and others (1951) lack sufficient detail to prove a major unconformity, and my reconnaissance of several areas where the contact between Havallah and Triassic rocks is shown on those maps did not reveal convincing structural evidence of a major tectonic event. Significant deposits of coarse-grained orogenic sediments of Late Permian to Early Triassic age are nowhere to be found.

According to Silberling and Roberts (1962) "Evidence for orogeny during Permian time is best illustrated in the China Mountain area $* * *$ where the Havallah Formation of Pennsylvanian and Permian age has been tightly folded and thrust-faulted and is overlain unconformably by the Koipato Formation***." However, according to Stewart and others $(1977,1986)$ the Havallah on the southeast side of the mountain is not tightly folded but is a structural package composed of northwest-dipping, nearly homoclinal strata that are sliced by numerous, inconspicuous, undated faults subparallel to bedding. Stewart and others (1986) state that "No folds of sufficient size to duplicate the map subunits have been observed, and no major overturned successions can be identified***." These authors do not discuss the basal contact of the overlying Koipato except to say that it is unconformable, but that might also be an inconspicuous undated fault. Figure 2 of Stewart and others (1986) showing the contact as a "sedimentary or fault contact" implies that possibility.

In the East Range where the base of the Rochester Rhyolite member of the Koipato Formation was mapped in some detail by Whitebread (1994), the base of the Koipato is shown to follow faithfully the bedding in underlying Permian strata that he assigned to the Havallah sequence. Also, the close similarity between felsites of the Inskip and the overlying Rochester Rhyolite indicates that felsitic magma generation and emplacement continued across the PaleozoicTriassic boundary. It is therefore hard to believe that this contact represents a major tectonic event characterized by folding and thrust faulting.

The substrate of the Koipato is also pertinent to the nature of the Sonoma orogeny. According to Silberling and Roberts (1962), “***beds depositionally underlying the Koipato sequence, wherever exposed, belong to the Havallah sequence***." If the contact between the Koipato and Havallah represents a major tectonic event, why does the Koipato not overlap the contact in many places and lie directly on pre-Havallah units? In one area in the eastcentral East Range, Ferguson and others (1951) showed the Koipato directly overlying the Leach Formation (now the mainly Ordovician Valmy Formation), and they state that this demonstrates a major unconformity in which the Havallah has been entirely eroded away. On later maps, however, Silberling and Roberts (1962), Johnson (1977), Stewart and Carlson (1978), and Crafford (2007) interpreted the formation underlying the Koipato at that location as the Havallah sequence, thereby eliminating a major unconformity in an area where it seemed imperative.

The age of the Golconda thrust is even more uncertain than the existence of the Sonoma orogeny, and this uncertainty has been explored by many authors without the development of a consensus. Silberling and Roberts (1962) express this uncertainty in their often-cited report defining the Sonoma orogeny and exploring its relation to the Golconda thrust. "Until more reliable information is available the ages of the Koipato sequence and the Edna Mountain Formation do not preclude development of the Golconda thrust during the Sonoma orogeny." They leave the question of linkage between the Golconda thrust and the Sonoma orogeny open to the possibility that the Golconda is of post-Triassic age. Gabrielse and others (1983) expressed the same degree of uncertainty: "All evidence on the age of the Golconda thrust, however, is equivocal, and the issue is unresolved."

Arguments for the distance traveled by the Golconda allochthon are also open to reinterpretation. The close proximity of contrasting deepwater Havallah and the partially contemporaneous shallow-water deposits (Antler sequence) separated by the Golconda thrust at Battle Mountain, Edna Mountain, and the Osgood Mountains has led to the hypothesis that the Havallah is a far-traveled allochthon (for example, Brueckner and Snyder, 1985). An alternative explanation is that the depositional basin of the Havallah and correlatives was bounded on the east by a high-angle fault and that the contrasting deep and shallow depositional environments were therefore originally possibly close together. In any event, the distance traveled by the allochthon is a matter of opinion in the absence of any convincing evidence.

In contrast to the apparent weakness of the evidence for intense deformation of Late Permian or Early Triassic age and lack of evidence for thrusting of that age, several detailed maps of local areas show unequivocally that the entire Triassic sequence was intensely folded and faulted in Jurassic or later time. Examples of such maps are those by Gilluly (1967), Whitebread (1994), Wallace, Silberling, and others (1969), Wallace, Tatlock, and others (1969), and Silberling and Wallace (1967).

\section{Conclusions}

Cambrian, Ordovician, and lowest Silurian strata of the arkosic triangle form a depositionally continuous part of the outer miogeocline and are indigenous to that area. Sequences variously termed Inskip, Havallah, and Harmony lie on those lower Paleozoic miogeoclinal strata depositionally and are therefore indigenous to the area also. The Inskip Formation, 
equivalent strata in the Hot Springs Range, and arkosic strata termed Harmony in several ranges constitute a facies of the Havallah sequence exposed widely within the arkosic triangle, and the entire assemblage was deposited in the same faultbounded basin or trough within the outer miogeocline. This assemblage therefore constitutes a single genetic stratigraphic unit (the Harvallahskip assemblage?) that has since been structurally disrupted.

Sediments composing this assemblage came from both sides of the depositional basin. Arkosic sands, olistoliths, and probably other detrital components, came from the west as argued by Ketner and others (2005). Clasts of quartzite, chert, and other components probably came from the east. The giant size of some olistoliths indicates the western source of these clasts was very close to the depositional basin.

Throughout the Late Devonian to Permian interval, basaltic and felsic magmas repeatedly erupted into sediments still saturated with seawater and into the sea itself. The Cambrian to Permian sequence was topped depositionally with mild structural discordance by Triassic rocks and was strongly folded with those Triassic rocks in Jurassic or later time.

Paleozoic tectonic activity within the arkosic triangle was expressed as: (1) Devonian elevation and erosion of part of the outer miogeocline; (2) Late Devonian depression of the same area, forming a trough, probably fault-bounded, in which the middle to upper Paleozoic assemblage was deposited; (3) Mississippian partial erosion of the arkosic deposits and deposition of resulting intraformational and extrabasinal conglomerates derived from those deposits; and (4) midPennsylvanian uplift and folding, or tilting, of the east side of the depositional basin resulting in an angular unconformity beneath certain Pennsylvanian to Permian strata.

The middle to upper Paleozoic basinal assemblage was compressed in the Jurassic or later, producing east-vergent thrusts in the eastern part of the depositional basin (Golconda thrust) and west-vergent thrusts and folds in the western part.

Stratigraphic and tectonic concepts dating from the early 1970s involving subduction and a far-traveled Golconda allochthon that was obducted onto the continent in the Early Triassic from a distant oceanic or back-arc basin are incompatible with modern observations as cited in the present report.

\section{Acknowledgments}

For geologic information on the Hot Springs Range, I have relied almost entirely on the published work of A. Elizabeth Jones Crafford and on conversations with her. Thanks to Linda and Michael McCollum for steering me to olistoliths and other important features of the Scott Canyon Formation in the Battle Mountain area. For paleontological support, I relied on John Repetski, Anita Harris, and Bruce Wardlaw all of the U.S. Geological Survey. Reviews by A. Elizabeth Jones Crafford and Patricia Cashman have improved the manuscript and are greatly appreciated.

\section{References Cited}

Brueckner, H.K., and Snyder, W.S., 1985, Structure of the Havallah sequence, Golconda allochthon, NevadaEvidence for prolonged evolution in an accretionary prism: Geological Society of America Bulletin, v. 96, p. 1113-1130.

Crafford, A.E.J., 2007, Geologic map of Nevada: U.S. Geological Survey Data Series 249, scale 1:250,000, 1 CD-ROM, 46 p., 1 plate, URL: http://pubs.usgs.gov/ $d s / 2007 / 249 /$.

Crafford, A.E.J., 2008, Paleozoic tectonic domains of Nevada-An interpretive discussion to accompany the geologic map of Nevada: Geosphere, v. 4, no. 1, p. 260-291.

DeBrenne, Françoise, Gandin, Anna, and Gangloff, R.A., 1990, Analyse sedimentologique et palentologie de calcaires organogenes, du cambrien inferieur de Battle Mountain (Nevada U.S.A.): Annales de Paleontologie, 1990, v. 76, p. 73-119. Lengthy abstract in English.

Doebrich, J.L., 1994, Preliminary geologic map of the Galena Canyon quadrangle, Lander County, Nevada: U.S. Geological Survey Open-File Report 94-664, scale 1:24,000.

Ferguson, H.G., Muller, S.W., and Roberts, R.J., 1951, Geologic map of the Winnemucca quadrangle, Nevada: U.S. Geological Survey Geologic Quadrangle Map GQ-11, scale 1:125,000.

Ferguson, H.G., Roberts, R.J., and Muller, S.W., 1952, Geologic map of the Golconda quadrangle: U.S. Geological Survey Geologic Quadrangle Map GQ-15, scale 1:125,000.

Gabrielse, Hubert, Snyder, S.W., and Stewart, J.H., 1983, Sonoma orogeny and Permian to Triassic tectonism in western North America: Geology, v. 11, no. 8, p. 484-486.

Gehrels, G.E., and Dickinson, W.R., 2000, Detrital zircon geochronology of the Antler overlap and foreland basin assemblages, Nevada, in Soreghan, M.J., and Gehrels, G.E., eds., Paleozoic and Triassic paleogeography and tectonics of western Nevada and northern California: Boulder, Colorado, Geological Society of America Special Paper 347, p. 57-63.

Gehrels, G.E., Dickinson, W.R., Riley, B.C.D., Finney S.C., and Smith, M.T., 2000, Detrital zircon geochronology of the Roberts Mountains allochthon, Nevada, in Soreghan, M.J., and Gehrels, G.E., eds., Paleozoic and Triassic paleogeography and tectonics of western Nevada and northern California: Boulder, Colorado, Geological Society of America Special Paper 347, p. 19-42. 
Gilluly, James, 1967, Geologic map of the Winnemucca quadrangle, Pershing and Humboldt Counties, Nevada: U.S. Geological Survey, Geological Quadrangle Map GQ-656, scale 1:62,500.

Hargett, R.N., Northrup, C.J., and Snyder, W.S., 2000, Structural analysis of the Inskip Canyon area, East Range, Nevada-Insights into the architecture of early-middle Jurassic(?) shortening: Geological Society of America Abstracts with Programs, v. 32, no. 7, p. A-170.

Hotz, P.E., and Willden, Ronald, 1964, Geology and mineral deposits of the Osgood Mountains quadrangle, Humboldt County, Nevada: U.S. Geological Survey Professional Paper 431, 128 p.

Johnson, M.G., 1977, Geology and mineral deposits of Pershing County, Nevada: Nevada Bureau of Mines and Geology Bulletin 89, 115 p.

Jones, A.E., 1991a, Teconic significance of Paleozoic and Early Mesozoic terrane accretion in northern Nevada: Berkeley, University of California, Ph.D. dissertation, $256 \mathrm{p}$.

Jones, A.E., 1991b, Sedimentary rocks of the Golconda terrane-Provenance and paleogeographic implications, in Cooper, J.D., and Stevens, C.H., eds., Paleozoic paleogeography of the Western United States-II: Los Angeles, California, Society of Economic Paleontologists and Mineralogists, Pacific Section, v. 2, p. 783-800.

Jones, A.E., 1993, Northwest vergent folding in the Harmony Formation, north central Nevada-Lower Paleozoic tectonics revisited: Geological Society of America Abstracts with Programs, v. 25, no. 5, p. 59.

Jones, A.E., 1997a, Geologic map of the Hot Springs Peak quadrangle and the southeastern part of the Little Poverty quadrangle, Nevada: Nevada Bureau of Mines and Geology Field Studies Map 14, scale 1:24,000.

Jones, A.E., 1997b, Geologic map of the Delvada Spring quadrangle, Nevada: Nevada Bureau of Mines and Geology Field Studies Map 13, scale 1:24,000.

Jones, D.L., and Wrucke, C.T., 1978, Revised ages of chert in the Roberts Mountains allochthon, northern Nevada: Geological Society of America Abstracts with Programs, v. 10 , no. 3 , p. 111 .

Ketner, K.B., 1966, Comparison of Ordovician eugeosynclinal and miogeosynclinal quartzites of the Cordilleran geosyncline: U.S. Geological Survey Professional Paper 550-C, p. C54-C60.
Ketner, K.B., 1991, Stratigraphy and strata-bound lead-zincbarium mineralization of lower Paleozoic western-facies rocks in northeastern Nevada, in Raines, G.L., Lisle, R.E., Shafer, R.W., and Wilkinson, W.H., eds., Geology and ore deposits of the Great Basin: Geological Society of Nevada, Symposium Proceedings, p. 539-551.

Ketner, K.B., 1998, The nature and timing of tectonism in the western facies terrane of Nevada and California-An outline of evidence and interpretations derived from geologic maps of key areas: U.S. Geological Survey Professional Paper 1592, 19 p.

Ketner, K.B., Crafford, A.E. Jones, Harris, Anita G., Repetski, John E., and Wardlaw, Bruce R., 2005, Late Devonian to Mississippian arkosic rock derived from a granitic terrane in northwestern Nevada adds a new dimension to the Antler orogeny, in Rhoden, H.N., Steininger, R.C., and Vikre, P.G., eds., Window to the world: Geological Society of Nevada Symposium 2005, Reno, Nevada, May 2005, p. 135-145.

Ketner, K.B., Ehman, K.D., Repetski, J.E., Stamm, R.G., and Wardlaw, B.R., 1993, Paleozoic stratigraphy and tectonics in northernmost Nevada-Implications for the nature of the Antler orogeny: Geological Society of America Abstracts with Programs, v. 25, no. 5, p. 62.

Ketner, K.B., Repetski, J.E., Wardlaw, B.R., and Stamm, R.G., 1995, Geologic map of the Rowland-Bearpaw Mountain area, Elko County, Nevada: U.S. Geological Survey Miscellaneous Investigations Series Map I-2536, scale $1: 24,000$.

Ketner, K.B., and Ross, R.J., 1990, Geologic map of the northern Adobe Range, Elko County, Nevada: U.S. Geological Survey Miscellaneous Investigations Series Map I-2081, scale 1:24,000.

Ketner, K.B., Wardlaw, B.R., Harris, A.G., and Repetski, J.E., 2000, The East Range, northwestern Nevada-A neglected key to the tectonic history of the region, in Cluer, J.K., Price, J.G., Struhsacker, E.M., Hardyman, R.F., and Morris, C.L., eds., Geology and ore deposits 2000_-The Great Basin and beyond: Geological Society of Nevada Symposium Proceedings, May 15-18, 2000, p. 389-396.

McCollum, L.B., Buchanan, J.P., and McCollum, M.B., 1985, Devono-Mississippian sedimentary environment at the type Antler Orogen at Battle Mountain, Nevada: Geological Society of America Abstracts with Programs, v. 17, no. 7, p. 657.

McCollum, L.B., and McCollum, M.B., 1989, The Antler orogeny-A transpressional orogen within a transcurrent fault system: Geological Society of America, Abstracts with Programs, v. 21, no. 5, p. 114. 
McCollum, L.B., and McCollum, M.B., 1991, Paleozoic rocks of the Osgood Mountains, Nevada, in Raines, G.L., Lisle, R.E., Schafer, R.W., and Wilkinson, W.H., eds., Geology and ore deposits of the Great Basin: Geological Society of Nevada Symposium Proceedings, Reno, Nevada, p. 735-738.

McCollum, L.B., McCollum, M.B., Jones, D.L., and Repetski, J.E., 1987, The Scott Canyon Formation, Battle Mountain, Nevada-A structural amalgamation of the Ordovician Valmy Formation and Devonian Slaven Chert: Geological Society of America Abstracts with Programs, v. 19, no. 7, p. 764.

Muller, S.W., Ferguson, H.G., and Roberts, R.J., 1951, Geologic map of the Mount Tobin quadrangle, Nevada: U.S. Geological Survey Geologic Quadrangle Map GQ-11, scale 1:125,000.

Noble, P.J., Ketner, K.B., and McClellan, W., 1997, Early Silurian radiolaria from northern Nevada, U.S.A.: Marine Micropaleontology, v. 30, p. 215-223.

Roberts, R.J., 1964, Stratigraphy and structure of the Antler Peak quadrangle, Humboldt and Lander Counties, Nevada: U.S. Geological Survey Professional Paper 459-A, p. A1-A93.

Roberts, R.J., Hotz, P.E., Gilluly, James, and Ferguson, H.G., 1958, Paleozoic rocks of north-central Nevada: American Association of Petroleum Geologists Bulletin, v. 42, no. 12, p. 2813-2857.

Sando, W.J., 1993, Coralliferous carbonate shelves of Mississippian age, west side of Antler orogen, central Nevada: U.S. Geological Survey Bulletin 1988-F, p. F1-F29.

Silberling, N.J., 1975, Age relationships of the Golconda thrust fault, Sonoma Range, north-central Nevada: Geological Society of America Special Paper 163, 28 p.

Silberling, N.J., and Roberts, R.J., 1962, Pre-Tertiary stratigraphy and structure of northwestern Nevada: Geological Society of America Special Paper 72, 53 p.

Silberling, N.J., and Wallace, R.E., 1967, Geologic map of the Imlay quadrangle, Pershing County, Nevada: U.S. Geological Survey Geologic Quadrangle Map GQ-666, scale 1:62,500.

Stewart, J.H., and Carlson, J.E., 1978, Geologic map of Nevada: U.S. Geological Survey, scale 1:500,000.
Stewart, J.H., MacMillan, J.R., Nichols, K.M., and Stevens, C.H., 1977, Deep-water upper Paleozoic rocks in northcentral Nevada-A study of the type area of the Havallah Formation, in Stewart, J.H., and Stevens, C.H., eds., Paleozoic paleogeography of the western United States: Pacific section of the Society of Economic Paleontologists and Mineralogists, Pacific Coast Paleogeography Symposium 1, April 22, 1977, p. 337-347.

Stewart, J.H., Murchey, Benita, Jones, D.L., and Wardlaw, B.R., 1986, Paleontological evidence for complex tectonic interlayering of Mississippian to Permian deep-water rocks of the Golconda allochthon in Tobin Range, north-central Nevada: Geological Society of America Bulletin, v. 97, p. 1122-1132.

Theodore, T.G., 1994, Preliminary geologic map of the Snow Gulch quadrangle, Humboldt and Lander Counties, Nevada: U.S. Geological Survey Open-File Report 94-436, scale 1:24,000.

Wallace, R.E., and Silberling, N.J., 1964, Westward tectonic overriding during Mesozoic time in north-central Nevada: U.S. Geological Survey Professional Paper 501-C, p. C10-C13.

Wallace, R.E., Silberling, N.J., Irwin, W.P., and Tatlock, D.B., 1969, Geologic map of the Buffalo Mountain quadrangle, Pershing and Churchill Counties, Nevada: U.S. Geological Survey Geologic Quadrangle Map GQ-821, scale 1:62,500.

Wallace, R.E., Tatlock, D.B., Silberling, N.J., and Irwin, W.P., 1969, Geologic map of the Unionville quadrangle, Pershing County, Nevada: U.S. Geological Survey Geologic Quadrangle Map, GQ-820, scale 1:62,500.

Webby, B.D., Paris, Florentin, Droser, M.L., and Percival, I.G., eds., 2004, The Great Ordovician biodiversification event: New York, Columbia University Press, 484 p.

Whitebread, D.H., 1978, Preliminary geologic map of the Dun Glen quadrangle, Pershing County, Nevada: U.S. Geological Survey Open-File Report 78-407, scale 1:48,000.

Whitebread, D.H., 1994, Geologic map of the Dun Glen quadrangle, Pershing County, Nevada: U.S. Geological Survey Miscellaneous Investigations Map I-2409, scale 1:48,000.

Whitebread, D.H., and Sorensen, M.L., 1983, Preliminary geologic map of the Kyle Hot Springs 7.5-minute quadrangle, Pershing County, Nevada: U.S. Geological Survey Open-File Report 83-393, scale 1:24,000. 
Publishing support provided by:

Denver Publishing Service Center

Manuscript approved for publication August 18, 2008.

For more information concerning this publication, contact:

Team Chief Scientist, USGS Central Energy Resources

Box 25046, Mail Stop 939

Denver, CO 80225

(303) 236-1647

Or visit the Central Energy Resources Team site at: http://energy.cr.usgs.gov/ 
